\title{
THE IMPORTANCE OF POST-ACQUISITION INTEGRATION FOR VALUE CREATION AND SUCCESS OF MERGERS AND ACQUISITIONS
}

\author{
Sladjana Savovic* \\ Faculty of Economics, University of Kragujevac, Kragujevac, Serbia
}

\begin{abstract}
Companies often resort to mergers and acquisitions in order to gain access to new markets, introduce new products, expand their knowledge-base or improve the competitive advantage. Achieving success in mergers and acquisitions represents complex managerial challenges, as a great number of these transactions fail in creating value for shareholders. Post-acquisition integration is the most challenging phase during which value creation should be involved, but which may also involve numerous integration problems. This study puts an emphasis on the success factors of the post-acquisition integration of companies, such as an integration strategy, the composition of the integration team, communications, the speed of the integration process and the uniformity of measurements. A special emphasis is put on the importance of the speed of integration as a success factor of the post-acquisition integration of companies.
\end{abstract}

Keywords: post-acquisition integration, key success factors, integration speed, success of mergers and acquisitions

\section{INTRODUCTION}

Resorting to acquisition processes reflects the efforts of companies to gain access to new markets or technologies, as well as to increase their efficiency by achieving economies of scale, economies of scope or economies of learning. At the same time, acquisitions are complex phenomena, and conditions under which they create or destroy value remain unclear despite numerous researches in the fields of finance and

\footnotetext{
* Correspondence to: S. Savovic, Faculty of Economics, University of Kragujevac, Dj. Pucara 3, 34000 Kragujevac, Serbia; e-mail: ssladjana@kg.ac.rs
}

management. The research done by consulting and auditing companies as well as the scientific research are dominated by the conclusion that the failure rate of the acquisition transactions is $50 \%$ on average, meaning that only one half of the performed acquisitions are successful (Kelly et al, 1999; Adolph et al, 2001; Marks \& Mirvis, 2001). Therefore, the focus of the research, both on a practical and a theoretical level, is on the identifying of the means to increase the success rate of mergers and acquisitions.

Research of mergers and acquisitions can be grouped into four major categories, or perspectives: financial, strategic, organizational and process-oriented 
(Birkinshaw, Bresman \& Hakanson, 2000). Value creation occurs in the period following an acquisition, which is the reason why researchers' attention has recently been focused on the process of post-acquisition integration. The research framework for studying postacquisition integration is found in an organizational and a process-oriented perspective. From the viewpoint of the organizational perspective, the research includes organizational behavior in acquisition processes (Marks \& Mirvis, 2001), while the process-oriented perspective studies potential problems in managing change during the integration (Birkinshaw, Bresman \& Hakanson, 2000; Haspeslagh \& Jemison, 1991). The theory of the decision-making process, used in shedding light on integration processes, points to the fact that the top management creates a structural and a strategic context shaping the behavior of the organization members at different levels. Studying the success factors, a number of researchers came to the conclusion that managing different elements of an integration process is the key determinant of a post-acquisition outcome. Managing the problem-solving of an integration process can create a competitive advantage for acquiring companies and enable them to develop successful growth strategies through acquisitions. Successful post-acquisition integration also depends on whether the leading team will recognize the right moments in the integration process to take a decisive action.

The aim of the study is to show the possibilities for value creation during the process of the post-acquisition integration of companies, identify the key success factors and evaluate the influence of the integration speed on the efficiency of the given process, as well as on the overall success of the acquisitions. According to the research goal, the study is examining the following key hypothesis: if value is created after the acquisition, then the speed of integration has a great influence on the efficiency of such integration and the success of acquisition. The study will implement a qualitative methodology, based on the examination and descriptive analysis of the researched issue. Research will consult relevant literature based on theoretical generalizations and practical experience of the authors who dealt with subject matter. Based on relevant literature, the study will analyze the process of the post-acquisition integration of companies, examine the possibilities for value creation, problems that may emerge in the given process, and identify the success factors for the postacquisition integration of companies. Special attention will be paid to the analysis of the speed of integration as a success factor, the advantages and disadvantages of fast integrations, aiming to estimate the overall effect that speed has on the efficiency of such postacquisition integration and the overall success of the acquisition.

\section{POST-ACQUISITION INTEGRATION OF COMPANIES: DEFINITION AND LEVELS OF INTEGRATION}

The process of post-acquisition integration is usually seen as a long-term and open process, beginning at the moment of the acquisition (the signing of an agreement) and lasting several years afterwards. As such, it involves activities which should secure the effective and efficient management of organizational activities and resources with the aim of achieving a set of combined organizational goals. The process of post-acquisition integration can be viewed as an evolving organizational process, as the integration and combining of organizations and a series of management initiatives and planned activities related to issues such as determining the levels of integration, autonomy delegated to the acquired company, the speed of integration etc.

In the process of acquiring previously independent companies, a hybrid organization is formed, in which value creation depends on the adequate management of interdependencies. Pablo (1994) defines integration as changes in the arrangement of functional activities, organizational structures and systems, as well as the cultures of combined organizations in order to facilitate their consolidation within one functional entity. Lindgren (according to Teerikangas, 2006) defines integration as a process dealing with administrative, organizational (organizational structure, compensation and communication systems, financial systems), social (cultural system) and operative (production, marketing, R\&D) systems. It is a multidimensional process during which managers should make it more facile for all the 
departments to function harmoniously within the combined entity.

According to Shrivastava (1986), the primary problem of the efficient management of ab acquisition process lies in the integration of two companies into a single entity. Post-acquisition integration can be executed on three different levels, depending on the acquisition circumstances. The first level is procedural (legal and accounting integration), the second level is physical (the integration of production lines and technology) and the third level is management- and socio-cultural integration (changes in the organizational structure, the development of the organizational culture, the selection of the management). The larger the companies are, the harder it is to execute integration, due to a large number of units needing coordination. Shrivastava stresses the importance of the adequate integration of companies' joint operations. On the other hand, there are authors (Pitkethly, et al, 2003, 33) stating that it is less important how well businesses are integrated, but rather whether their integration has been executed on an adequate level. The levels of integration can be ranked from low to high: the acquired company can remain independent after the acquisition (non-integrated companies), the acquiring company can adapt to the acquired company (partially integrated companies) and companies can merge into one organization (totally integrated companies) (Figure $1)$.
The low level of integration is such that technical and administrative changes are limited to sharing financial risks and resources, and the standardization of basic management systems and processes in order to facilitate communication. The moderate level of integration assumes more substantial changes in the value chain, as well as the sharing and exchange of physical resources based on learning. Administrative changes at this level may include selective modifications in reporting relations and authority delegations. At the highest level of integration, integration involves sharing all types of resources, implementing operations systems, planning and control systems and company's procedures previously used by the acquiring company, as well as the complete structural and cultural absorption of the acquired company (Pablo, 1994).

Attempting to identify "ideal" integration approaches, authors Kimberly \& Lamont (2004) begin with studies conducted by Nahavandi \& Malekzadeh (1988), Haspeslagh \& Jemison (1991) and Marks \& Mirvis (1998). Nahavandi \& Malekzadeh (1988) studied the process of the harmonization of cultures within postacquisition integration and identified different models based on two primary dimensions - a degree of relatedness between the two companies and a degree of tolerance for different cultures by the acquiring company. These authors provide a short description of different ways for culture harmonization separation, assimilation, integration and deculturation. Haspeslagh \& Jemison (1991) developed a framework

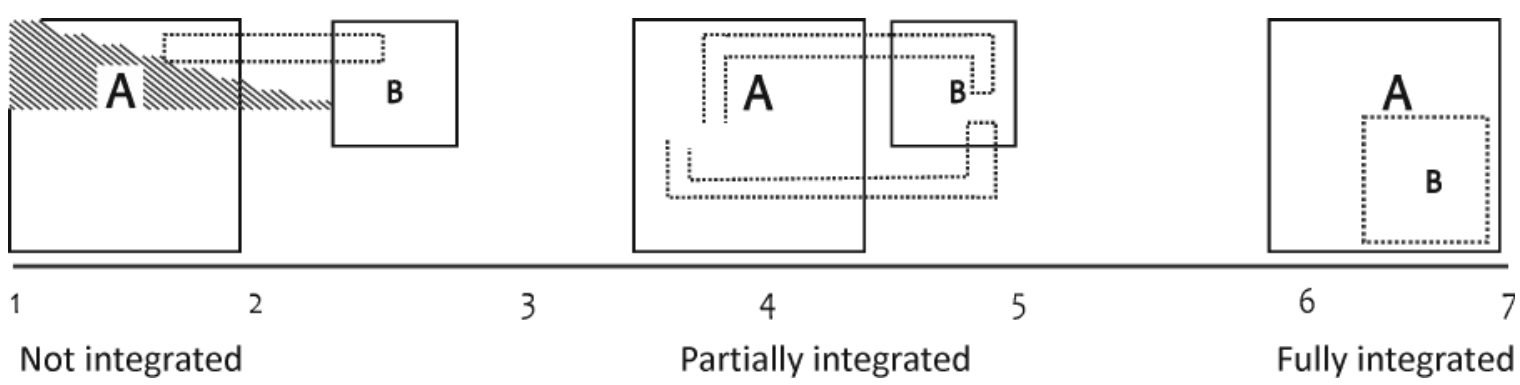

Figure 1 Spectrum of integration 
pointing to the dependence of an adequate form of integration on the two key requirements: a degree of the strategic interdependence of the two companies and the need for achieving organizational autonomy. Based on these two requirements, there can be four types of integration: absorption, symbiotic, protection and holding (Fanlkner \& Cambell, 2003, 109-112). Marks \& Mirvis (Kimberly \& Lamont, 2004) discuss several main ways for companies to combine their operations after acquisition. Using the degree of postacquisition changes in both companies as the basis for their classification scheme, these authors identify and describe organizational attributes necessary for the successful management of the major integration approaches - absorption, reverse merger/assimilation, preservation, the best of both, and transformation. Figure 2 shows the overlapping of different integration approaches.

Integration through absorption is suggested when the need for strategic interdependence is high and the need for an organizational autonomy is low, and its aim is to realize the complete consolidation of the operations, structure and cultures of the two companies. As this approach usually involves a substantial degree of change in the acquired company, its implementation must be executed in a predefined, consistent and fast manner, in order to minimize possible disorders and uncertainties which can exist in the post-acquisition

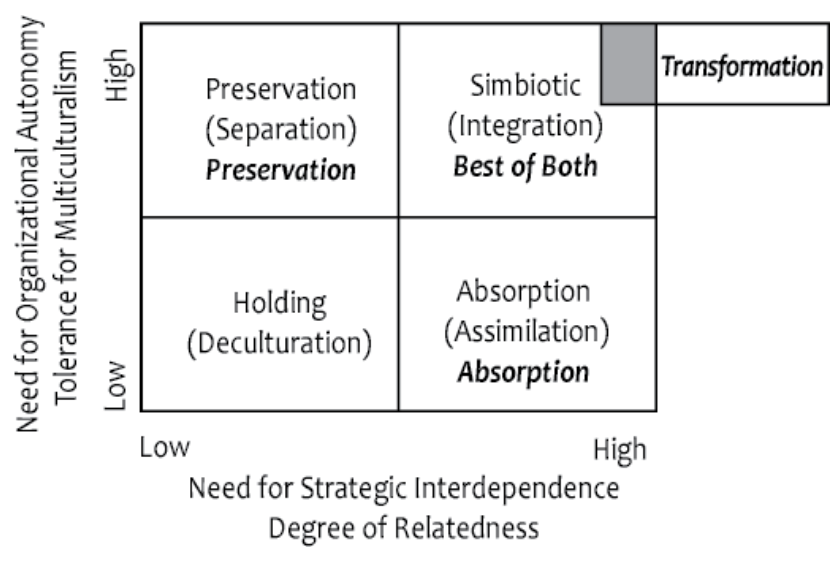

Figure 2 Integration approaches

Source: Kimberly \& Lamont, 2004 integration process. Integration through symbiotic assumes that the acquiring company is attempting to establish a balance between two business models in such a way as not to have the organizational autonomy of the acquired company endangered by transferring strategic competences. This approach includes a period of initial protection (the preservation of the existing state), followed by a period of a gradual involvement (merging, combining) of the best practices from both companies. This process of integration requires a degree of change in both companies in order to create a combined company which reflects the key competences and the leading practices of both companies (Kimberly \& Lamont, 2004, 81-102).

Integration through preservation is suggested when the acquired company is required to maintain a high degree of autonomy and when the need for strategic interdependence is low. In this form of integration, the newly-acquired company continues to operate independently. Essentially, this approach involves few changes in the acquired company, as the primary driver of the post-acquisition success is the ability to maintain the strategic competences of the acquired company intact. Holding refers to a situation in which the acquiring company acts essentially as a holding company with no intention to integrate the two companies. This approach assumes the existence of a low degree of strategic interdependences, while the acquired company is not allowed a high degree of autonomy. In practice at times, it is not easy to make a clear difference between the categories of holding and preservation. However, in his work, Pitkethly el al (2003) states that Angwin puts a greater focus on the two categories by differentiating the holding category, where the acquiring company is attempting a turnaround, but without any degree of integration, from the preservation approach, where the acquired company remains unintegrated, but with the intention of maintaining good profits. While symbiosis assumes a certain degree of changes in both companies, when the best practices are implemented, sometimes such an integration process involves very important, fundamental changes in the organizational cultures and operative practices of both companies. In such cases where both companies are disbanded as part of integration efforts, the form of combining operations is known under the name of the transformational 
approach. The approach requires that the newlycombined company should completely reinvent itself by creating a new organization, a set of values and a way of operating, instead of combining the best elements of both of the original companies. Which integration approach will be applied depends on the type of acquisition and the business characteristics. Each integration approach has its specific obstacles. For example, the absorption of the acquired company can cause resistance to change amongst its employees and high employee turnovers. With a symbiotic approach, the creation of a new organization and the selection of the management within such a new structure can destroy cooperative atmosphere, while a preservation approach involves the challenge of maintaining clear borders between companies.

\section{POSSIBILITIES FOR VALUE CREATION AND ISSUES DURING POST-ACQUISITION INTEGRATION OF COMPANIES}

A number of authors (Datta, 1991; Pablo, 1994; Larsson \& Finkelstein, 1999) stress that the potential of the strategic combination is not realized automatically, and that the degree of synergy realization depends on how such a new organization is managed after the acquisition is completed. Larsson \& Finkelstein (1999) define integration as the degree of interaction and coordination between the two companies involved in the processes of mergers or acquisitions, and stress that it has great importance in realizing potential synergies, because poorly implemented interaction and coordination will not lead to achieving joint benefits.

Post-acquisition integration is the motor of organizational change and development, and it plays the key role in an overall regeneration strategy. It includes post-acquisition reconfiguration, redeployment and the disposal of the tangible and intangible resources of both companies (Chakrabarti \& Mitchell, 2004). It is a process of adaptation in which the acquiring company and the acquired company perform a transfer of competences and work on achieving acquisition goals.

Post-acquisition integration can be described as a process involving at least two phases - "the first 100 days" and the phase of "transfer of competences". The
"First 100 days" phase begins immediately after the realization of an acquisition and the main goals of this phase maintain the impulses of both companies and the creation of a favorable climate for exploiting synergies. The First 100 days and weeks after the announcement of an acquisition are characterized by the presence of uncertainty: many employees experience fear due to uncertainty and it is necessary to pacify them and secure their commitment to new projects. When an adequate atmosphere is created, the acquiring company can focus on the phase of transferring competences. The goal of this phase is to use synergies in order to create value expected from the transaction (Gates \& Very, 2003, 165-185).

The integration of the acquiring- and the acquired companies in a legal, structural and cultural sense is an important factor in creating value and achieving a success in mergers and acquisitions. It is composed of interactions constituting the environment for the transfer of competences, which can create value and facilitate the realization of the purpose of mergers and acquisitions. Haspeslagh \& Jemison (1991) differentiate various types of transfer of competences: resource distribution, transfer of knowledge (or skills), transfer of management skills, which leads to improving competitive advantages. Sharing of resources involves the combination and rationalization of certain operative assets of the two companies, leading to a decrease in costs due to economies of scale and scope. Resource sharing is generally based on the existence of similarities between such two companies and is often implemented in acquisitions within the same industry. Knowledge transfer involves sharing knowledge which creates value, such as production technology, marketing know-how or financial control skills. Additional value can be created through resulting lower costs or the improvement of the market position, which leads to an increase in income and/or margins. The third source of value is based on the transfer of strategic logic for change management in the acquired company. A new management team often brings an improved competitive position of such a company, thus contributing to an increase in its income. This team may also contribute to achieving cost reductions if the previous team was profligate (Fanlkner \& Cambell, 2003, 95-117). 
Stressing the importance of integration for value creation and the success of mergers and acquisitions, authors agree that many integration issues exist, which, if not adequately handled, can prevent synergy realization. Integration issues may arise out of employees' resistance and incompatible cultures. Postacquisition changes often involve labor reductions and structural redesigning with the goal of decreasing costs and redundancies. Such organizational and personal changes create an atmosphere of psychological insecurity and uncertainty for employees. Such circumstances create increasing differentiations within groups, forming scenarios of winners-losers and general mistrust. A lack of predictability and the poor familiarity of employees with the current state of the company, leads to confusion and anxiety (Elsass \& Veiga, 2006, 95-105). The impact of such organizational changes is particularly serious on employees who think that they have no control over change forces. Such employees will probably feel a more extensive decrease in control at work and helplessness, and will psychologically be dislocated from the work they perform, or will show resistance to change (Chakrabarti \& Mitchell, 2004).

Larsson \& Finkelstein (1999) find that employee resistance decreases the utilization of possible synergies. They defined resistance as an individual and collective opposition of employees to the combination and integration of companies, which negatively affects the performance of mergers and acquisitions. Opposition can be active (willing exit from such an organization, sabotage) or passive (missing from work, disobedience) and is expected to substantially decrease the realization of synergies during the integration process. Birkinshaw et al (2000) conclude that the bad management of human resources negatively impacts the overall progress of the integration phase. Stress, insecurity, and rumors regarding a merger or an acquisition affect the financial and operative performance of a company.

Cultural incompatibility is often cited as a source of post-acquisition issues (Nahavandi \& Malekzadeh, 1988), which may lead to the misuse of synergies. Some empirical data point to a conclusion that higher cultural differences lead to higher integration problems and thus lower post-acquisition performances (Datta,
1991). On the other hand, the presence of a developed corporate culture in the acquiring company can positively affect performance, if it is efficiently transferred to the acquired company (Chakrabarti \& Mitchell, 2004).

Integration issues may present serious obstacles to an acquisition success; however, they can be managed. An important role in managing the process of postacquisition integration and overcoming possible issues is given to transformational leaders who should lead the critical mass of employees through a period of great uncertainty, secure the continuity of operations and teach employees a new behavior pattern (Babić \& Savović, 2009). Transformational leadership is more effective than transactional leadership in situations of uncertainty or a crisis, such as the integration process. Transformational leaders encourage employees to strive for common goals and interests. In such a way, a positive interpersonal relationship is developed between team members and a micro-context in which employees share the existing and develop new knowledge is formed (Nemanich \& Vera, 2009).

Transformational leaders have capabilities and skills to motivate employees to form a new way of thinking, destroying the existing paradigms and creating new ones. The goal of these leaders is to communicate a wellarticulated vision, create a feeling of belonging and encourage employees to adapt to changes. One's ability to lead employees and establish a new business identity, which allows the adoption of a new common vision, and - even more importantly - develops the feeling of common connection and belonging, are of crucial importance for the successful assimilation of groups or the creation of new groups. By communicating such a common vision, transformational leaders facilitate their employees' comprehension of changes in their business environment, thus enabling them to adequately respond to them. Encouraging employee involvement in redesigning operations is recommended as a useful way of decreasing possible resistance during transition. Also, communicating with employees regarding the anticipated effects of such changes contributes to a decrease in insecurity and worry (Schweiger \& DeNisi, 1991) and an increase in their commitment to the integration process (Schweizer \& Patzelt, 2012) 


\section{KEY SUCCESS FACTORS OF POST- ACQUISITION INTEGRATION OF COMPANIES}

An important segment of the acquisition-related research is focused on studying the post-acquisition integration of companies. This is based on the premise that "value is created after an acquisition" and that if post-acquisition activities are well-managed - the probability of a successful acquisition is increased. A number of scientific workers, consulting companies and experts in the field attempted to answer the question of which factors determine the success of post-acquisition integration.

De Noble et al $(1988,51-59)$ state the following factors: having a clear and precise vision prior to the end of an acquisition, forming a cross-fertilize management team, a continued focus on employees, managing cultural differences, interconnectedness of the strategy and the structure and the speed of implementation. The study Making Acquisitions Work: Capturing Value After the Deal (Harbison et al. 1999) facilitated the development of a value framework, composed of 3 elements: vision, architecture and leadership, which are of essential importance for the success of post-acquisition integration (Table 1). In order for companies to be successfully integrated, all the three essential elements must be very familiar. If the vision of the new company is not defined, the company is missing the focus and direction and will not be able to create value for new buyers or what the basis of its competitive advantage is and how it will accomplish its goals. Without a wellstructured integration process, or, in other words, a right architecture, the new company will be engulfed in chaos. Key decisions refer to determining business segments which need to be integrated and the speed of integration implementation. Finally, if efficient leadership is missing, necessary changes will not be made in either company and at all levels. The research has shown that a failure in determining all the three elements can lead to value destruction. In order for a company to successfully implement the process of post-acquisition integration, it is necessary to create a new vision for the new entity and plan details from the beginning, identifying the sources of value and the means of their adoption, understanding the importance of strategic leadership which will help in the implementation of such necessary changes and move the competences of the new company toward achieving a maximum profit and growth (Harbison et al, 1999).

The study Merger Integration: Delivering on the Promise (Adolph et al, 2001), states the four key principles necessary for the success of post-acquisition integration: the communication of a vision for value creation, seizing the defining moments to make explicit choices and trade-offs (defining the character and speed of an integration process), simultaneous execution against competing critical imperatives and the employment of a rigorous integration planning process.

The report After the Merger: Seven Rules for Successful Post-Merger Integration stresses several factors important in the post-acquisition phase, including: the early placement of integration managers, defining their roles, fast and efficient communications with employees in order for them to be properly oriented towards achieving corporate goals (Habeck et al, 2000).

Epstein (2004) emphasizes five success drivers of post-acquisition integration: a coherent integration strategy, a serious integration team, communications,

Table 1 Three elements necessary for change

\begin{tabular}{|c|c|c|c|}
\hline Vision & $\begin{array}{l}\text { Architec- } \\
\text { ture }\end{array}$ & $\begin{array}{l}\text { Leader- } \\
\text { ship }\end{array}$ & Outcome \\
\hline$\bullet$ & $\bullet$ & $\bullet$ & $\begin{array}{l}\text { Successful post-acqui- } \\
\text { sition integration }\end{array}$ \\
\hline$\bullet$ & $\bullet$ & O & $\begin{array}{l}\text { Change isn't cascaded } \\
\text { throughout both com- } \\
\text { panies or to all levels }\end{array}$ \\
\hline $\mathrm{O}$ & $\bullet$ & $\bullet$ & $\begin{array}{l}\text { No focus: New enter- } \\
\text { prise lacks direction }\end{array}$ \\
\hline$\bullet$ & O & $\bullet$ & $\begin{array}{l}\text { Chaos: No process for } \\
\text { integration }\end{array}$ \\
\hline$\bullet$ & O & O & An academic exercise \\
\hline $\mathrm{O}$ & $\bullet$ & O & Bureaucracy \\
\hline $\mathrm{O}$ & $\mathrm{O}$ & $\bullet$ & Empty charisma \\
\hline
\end{tabular}

Source: Harbison et al, 1999, 8 
the speed of integration, aligned measures (Table 2). The failure of any of these five factors can prevent the achievement of acquisition goals. While some factors can easily be controlled a through careful design and implementation, the other ones are more challenging due to numerous external forces.

In a study conducted by consulting firm Oliver Wyman, the following key success drivers in integration are emphasized: the types of synergy to be achieved, speed, a degree of integration, the starting point of integration work, the composition of an integration team, an approach in making key decisions, a degree of communication and change management (Wyman et al, 2008, 1-16). In the most recent study PWC
Putting the pieces together - Post-merger integration survey 2010, the following factors of an integration success are studied: synergy monitoring, defining and managing deadlines, budgeting integration costs, planning integration, the placement of the integration management, the forming and implementing of a communications strategy, managing cultural issues, involving different key people in integration management (Agrawal et al, 2011). Attempting to reach an answer to the question what it is that determines the success of post-acquisition integration, researchers discovered different factors. Summing up the results of empirical research and the relevant literature, the importance of integration speed is clearly observed as the key success factor.

Table 2 The five drivers of success in corporate integration

\begin{tabular}{|c|c|c|c|}
\hline & Merger & Acquisition & Conglomerate \\
\hline $\begin{array}{l}\text { Integration } \\
\text { Strategy }\end{array}$ & $\begin{array}{l}\text { Promote "merger of equals". } \\
\text { Meritocratic decisions. } \\
\text { Practices chosen without respect to } \\
\text { previous companies' practices. }\end{array}$ & $\begin{array}{l}\text { Create impression that acquired com- } \\
\text { pany was "always there".Acquired } \\
\text { company adopts practices of acquir- } \\
\text { ing company. }\end{array}$ & $\begin{array}{l}\text { No major changes in new company. } \\
\text { Assimilation of new company in cer- } \\
\text { tain key areas, and some oversight } \\
\text { functions added. }\end{array}$ \\
\hline $\begin{array}{l}\text { Integration } \\
\text { Team }\end{array}$ & $\begin{array}{l}\text { Full-time, discrete team with ample } \\
\text { resources and contributions from } \\
\text { senior management. } \\
\text { Equal contributions from both com- } \\
\text { panies. }\end{array}$ & $\begin{array}{l}\text { Small, discrete team with ample } \\
\text { resources and contributions from } \\
\text { senior management. } \\
\text { Leadership from acquired company } \\
\text { remains. }\end{array}$ & $\begin{array}{l}\text { Leadership from acquired company } \\
\text { remains. } \\
\text { Management participation in both } \\
\text { companies to promote knowledge. }\end{array}$ \\
\hline $\begin{array}{l}\text { Communica- } \\
\text { tion }\end{array}$ & $\begin{array}{l}\text { Customers of both companies must } \\
\text { understand changes in business. } \\
\text { Employees of both companies must } \\
\text { understand new roles and opportuni- } \\
\text { ties. } \\
\text { Focus on how companies fit together. }\end{array}$ & $\begin{array}{l}\text { Customers of acquired company must } \\
\text { understand new opportunities in } \\
\text { business. } \\
\text { Employees of acquired company } \\
\text { must understand new roles. } \\
\text { Focus on how acquired company fits } \\
\text { into acquiring company's business. }\end{array}$ & $\begin{array}{l}\text { Few changes for customers. } \\
\text { Parent company must understand } \\
\text { how new company operates and } \\
\text { any new synergies. } \\
\text { New company must understand } \\
\text { parent company's practices and } \\
\text { opportunities }\end{array}$ \\
\hline Speed & $\begin{array}{l}\text { Fast decisions are key for both strate- } \\
\text { gic goals and promoting stability and } \\
\text { reducing uncertainty in organization. }\end{array}$ & $\begin{array}{l}\text { Fast decisions are key for both strate- } \\
\text { gic goals and promoting stability and } \\
\text { reducing uncertainty in organization. }\end{array}$ & $\begin{array}{l}\text { Fast decisions are primarily impor- } \\
\text { tant for reducing uncertainty in } \\
\text { organization }\end{array}$ \\
\hline $\begin{array}{l}\text { Aligned Mea- } \\
\text { sures }\end{array}$ & $\begin{array}{l}\text { Balance between financial and non- } \\
\text { financial measures. } \\
\text { Tracking of revenue and const syner- } \\
\text { gies }\end{array}$ & $\begin{array}{l}\text { Focus on how acquired company } \\
\text { builds company growth and reduces } \\
\text { costs. } \\
\text { Acquired company adopts measure- } \\
\text { ment systems of acquiring company. }\end{array}$ & $\begin{array}{l}\text { Most internal measurement stays } \\
\text { same for new company. } \\
\text { New measures added to assimilate } \\
\text { new company into parent com- } \\
\text { pany. }\end{array}$ \\
\hline
\end{tabular}




\section{SPEED AS SUCCESS FACTOR OF POST- ACQUISITION INTEGRATION OF COMPANIES}

The speed of integration can be defined as a period of time necessary to implement the integration of systems, structures, activities and processes of two companies. There are numerous reasons why speed can be of imperative importance. From the financial perspective, time spends money, and the faster a post-acquisition integration is implemented, the sooner revenues will be realized. Observed from the behaviorist perspective, speed is important because it mitigates uncertainty which exists among employees and customers. Faster integration can shorten the exposure of employees to uncertainties and lower exponential effects of rumors. In the case of a fast post-acquisition integration, there is not much time for rumors to spread on the market, which leads to a reduced uncertainty for the customer. If decisions related to post-acquisition integration, which are relevant to customers, are made and implemented swiftly, buyers will know what to expect from the company in terms of the product supply, the price policy, the sales strategy, contact persons, etc. Besides, in business practice, it is common for competitors to the acquiring company to attempt to increase uncertainty among customers in order to win them over for themselves. This potential source of uncertainty for buyers can be reduced through fast post-acquisition integration. From the perspective of organizational change, an increase in integration speed can bring benefits to the organization through shorter time spent on coordination.

The literature related to integration speed covers studies by Epstein (2004), Homburg \& Bucerius $(2005,2006)$. Epstein (2004) indicates that speed is of essential importance to the success of post-acquisition integration and that fear and indecisiveness can often create barriers to quick actions. This author stresses that companies moving too slow in the integration process are faced with numerous threats especially in terms of the two key constituents (employees and customers). On the one hand, employees can request slower speed, as a sign of insecurity, or can tend to leave to competing companies, where they perceive the situation to be more stable. Customers, on the other hand, can feel fear and insecurity and may turn to competing products if the visible aspects of integration are not quickly realized. Besides, the author emphasizes that a slower pace can interfere with innovations and prevents companies from achieving synergies. Colombo et al (2007) emphasize that it is not enough to perform adequate activities for achieving acquisition goals, but that it is also necessary for them to be performed with maximum urgency.

A research conducted by Homburg \& Bucerius (2005) had the goal of observing the impact of postacquisition marketing integration on the performances and effects of the speed of integration. The results showed weak positive direct effects of integration speed on performance (based on stock price changes) after a merger or an acquisition. In a more recent study, Homburg \& Bucerius (2006) emphasize that fast integration brings benefits and also disadvantages, and that in certain situations, speed can bring great benefits, while in others it can negatively impact the success of acquisitions. According to the authors, benefits and disadvantages depend on the existence of the external (target market and market positioning) and internal (i.e. a management style) relatedness of companies prior to an acquisition. The research results show that speed creates value when external relatedness is low while the internal one is high.

There are authors who think that, under certain conditions, a slower approach to post-acquisition integration can be better than a faster approach (Bragado, 1992 according to Homburg \& Bucerius, 2006, 348). The key argument stated by Bragado is that it is necessary that employees of such two companies should be enabled a period of studying and understanding one another. This author emphasizes that an adequate speed of integration depends on the "fit" of involved companies, particularly cultural fit.

A certain number of consulting firms published results of their empirical studies related to the performances of mergers and acquisitions, which investigate the role of integration speed as a potential success factor (Harbison et al, 1999; PriceWaterhouseCoopers, 2000; Wyman et al, 2008). These studies provide certain data that integration speed can have a positive impact on the success of mergers and acquisitions. It is usually stressed that the fast implementation of changes is useful because it minimizes the scope of uncertainties 
among the employees of combined companies. The study by Harbison et al (1999) showed that, if companies are unequal in size, integration should be faster than in the case of similar-sized companies, as shown in Figure 3. A research carried out by Atos Consulting (2008) confirmed the importance of speed and clearly showed that a great number of organizations prefer speed during the realization of integration goals.

The research done by PricewaterhouseCoopers (2000) showed that, although all companies are faced with differences in their respective operating philosophies, management practices and information systems, those which conduct a transaction faster have substantially fewer problems than the slower ones. Slower transactions extend integration issues, while companies which implement the integration process faster overcome the "my-practice-is-betterthan-your-practice" debate and accompanying issues. Prolonged transactions cause additional costs, slower growth, destroy a profit and lower cash flows, thus prolonging payments. This research showed that benefits of faster transactions can be found in: faster returns on investment, exploiting chances in the period after acquisition, competitors' frustration in

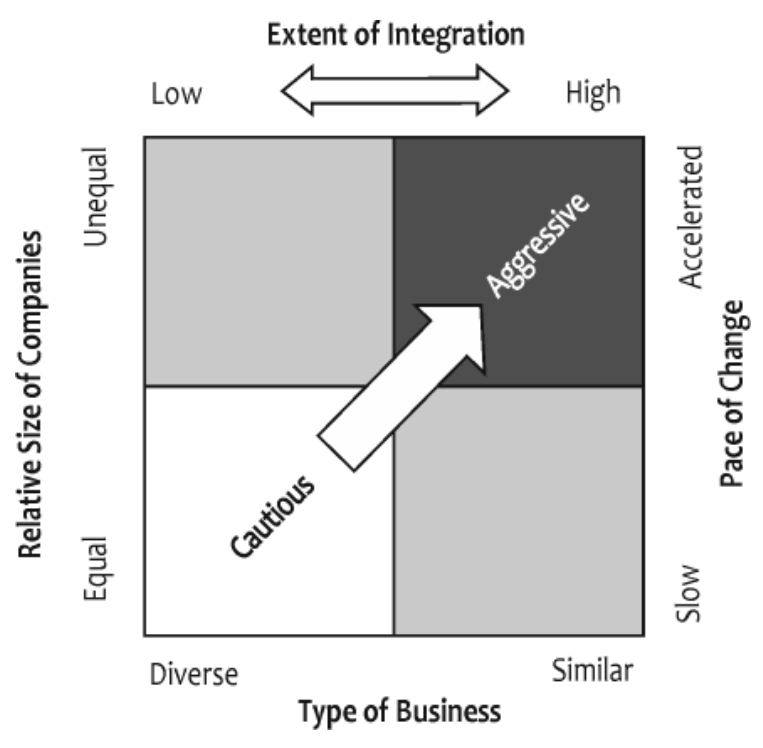

Figure 3 Degree and speed of integration

Source: Harbison et al, 1999, 12 their attempts to achieve an advantage, the reduction of organizational uncertainty. Companies faster in implementing post-acquisition integration have a better chance of achieving a financial and strategic success. Among companies fast in implementing necessary changes, $75 \%$ consider their transactions to have been been strategically successful and 58\% consider them financially successful. The percentages of success with companies which had longer transitory period are substantially lower $-43 \%$ and $24 \%$, respectively (Graph 1).

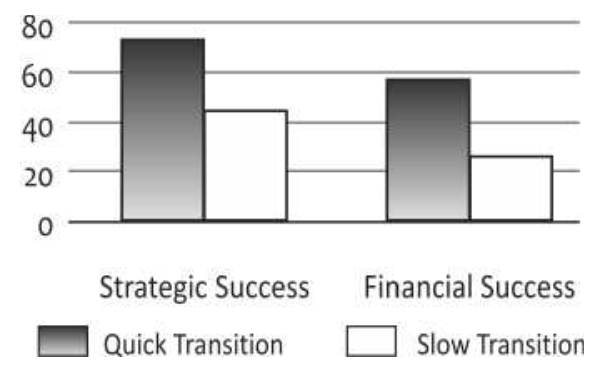

Graph 1 Achievement of financial and strategic success depending on integration speed

Source: PricewaterhouseCoopers, 2000

Companies moving faster through a transition period are quicker in conducting an integration process and communicating their new policies and operating procedures, and achieve higher gross margins and profits (Graph 2). Besides, faster transactions have a more favorable effect on cash flows and progress in achieving business goals. An early formulation of integration policies and procedures shows that the management provides necessary information to their employees. However, the management must first be certain that their new policies and procedures are supportive of a general business strategy and that they are well-understood within the organization. Wyman et al. (2008) consider that integration speed depends on the type of acquisition and that in hostile takeovers, integration should be implemented faster, while in friendly takeovers, a slower pace can increase a chance of success. 


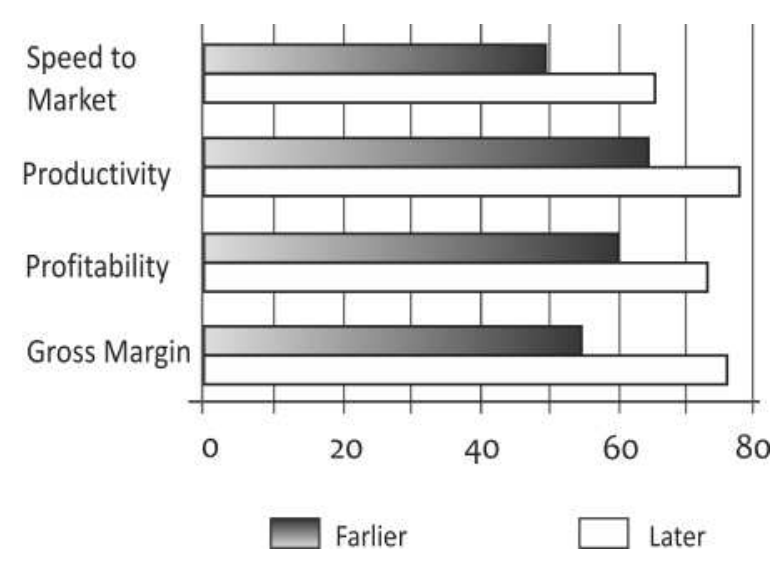

Graph 2 Impact of integration speed on performance improvement

Source: PricewaterhouseCoopers, 2000

Although not all authors have a uniform stand on the impact of speed on the success of post-acquisition integration, the dominant viewpoint is the one telling of a positive effect of speed. The most usual positive effects of integration speed stated relate to mitigating uncertainties, the faster realization of yields, a shorter time dedicated to coordination, a faster achievement of business goals, an increased probability of achieving a financial and strategic success.

\section{CONCLUSION}

Transactions of company acquisitions involve high risk and demand exceptional care in the process of planning and implementation, in order to achieve the desired goals and facilitate value creation. As it is obvious that value creation occurs after an acquisition, recently postacquisition integration has increasingly been attracting researchers' attention. The poor implementation of post-acquisition integration is cited as one of the main causes of failure of mergers and acquisitions. Therefore, it becomes a necessary precondition to conduct a detailed observation of integration mechanisms and identify the sources of value and possible issues and challenges within the integration phase. The main sources of value are the sharing of resources, the transfer of knowledge and management skills, while the key issues bringing about value destruction include employees' resistance and the incompatibility of cultures. Overcoming integration issues, which can create barriers to achieving a success in mergers and acquisitions, is possible with the adequate management of post-acquisition activities.

In the process of identifying factors of the key importance for the success of post-acquisition integration, and therefore for the success of mergers and acquisitions, special importance is given to the speed of integration. There is no full uniformity of the authors' opinions on the effects of speed; however, there is a prevalent opinion of the majority of them that speed has key importance for achieving strategic goals, promoting stability and reducing uncertainty in the organization. In order for a company to successfully implement the process of post-acquisition integration, it must create a new vision for the new entity and execute detailed planning, understanding the importance of strategic leadership which helps in the implementation of necessary changes and quickly activates the capabilities of the new company with the aim of achieving a maximum profit. An ability to quickly execute integration, reduce operating expenses and generate additional yields becomes the main factor in achieving good performances.

Having in mind the fact that only in recent times have the processes of mergers and acquisitions in Serbia become more important, the stated subject is not well researched. Therefore, there is a need for empirical research which, in a methodologically valid way, would test the process of post-acquisition integration, with the aim of better understanding the factors determining the success of the given process and the overall success of mergers and acquisitions. A comprehensive theoretical and empirical analysis of the stated issue would facilitate the comparison of reached results with the results of research in developed market economies.

\section{ACKNOWLEDGMENTS}

This research is a part of the interdisciplinary scientific Project (No. 41010), financed by the Ministry of Science, Republic of Serbia. 


\section{REFERENCES}

Adolph, G., Buchanan, I., Hornery, J., Jackson, B., Jones, J., Kihlstedt, T., Neilson, G., \& Quarls, H. (2001). Merger Integration: Delivering on the Promise. Booz Allen \& Hamilton. Retrieved April 10, 2010, from http://www.boozallen.com/ media/file/76776.pdf.

Agrawal, S., Dasgupta, A., \& Bansal S. (2011). Putting the pieces together - Post merger integration survey 2010, PwC India. Retrieved March 08, 2011, from http://www.pwc.com/in/en/ publications/publications-2011/putting-the-pieces-together. jhtml.

Atos Consulting. (2008). Post-merger Integration of It, White Paper - Challenging the CIO Before and After the Deal. Atos Origin., 1-16. Retrieved March 08, 2011, from http://www. be.atosconsulting.com/NR/rdonlyres/C8A81F41-6DE64DDD-9A63-930343774B91/0/AtosConsulting_Whitepaper_ PostMerger_Integration_of_IT_uk.pdf.

Babic, V., \& Savovic, S. (2009). Značaj liderstva za uspeh procesa preuzimanja preduzeća. Ekonomske teme, 1, 74-61.

Birkinshaw, J., Bresman, H., \& Hakanson, L. (2000). Managing the Post-Acquisition Integration Process: How the Human Integration and Task Integration Processes Interact to Foster Value Creation. Journal of Management Studies, 37(3), 395-421.

Chakrabarti, A., \& Mitchell, W. (2004). A Corporate Level Perspective on Acquisitions and Integration. Retrieved February, 15, 2011, from http://faculty.fuqua.duke.edu/ willm/bio/cv/ papers/AIMA2004_integration.pdf.

Colombo, G., Conca, V., Buongiorno, M., \& Gnan, L. (2007). Integrating Cross-Border Acquisitions: A Process-oriented Approach. Long Range Planning, 40, 202-222.

De Noble, A., Gustafson, L., \& Hergert, M. (1997). Planning for Post-merger Integration - Eight Lessons for Merger Success. In B. Lloyd (Ed.), Creating Value through Acquisitions, Demergers, Buyouts and Alliances (pp 51-59).

Datta, K. D. (1991). Organizational Fit and Acquisition Performance-Effects of Post-acquisition Integration. Strategic Management Journal. In Risberg, A., (2006). Mergers and Acquisitions - A Critical Reader. Routledge Taylor \& Francis Group.

Elsass, M. P., \& Veiga, F. J. (1994). Acculturation in Acquired Organizations: A Force-field Perspective. Human Relations. In Risberg, A. (2006). Mergers and Acquisitions A Critical Reader. Routledge Taylor \& Francis Group.

Epstein, M. (2004). The Drivers of Success in Post-Merger Integration, Organizational Dynamics, 33(2), 174-189.
Fanlkner, D., \& Cambell, A. (2003). The Oxford Handbook of Strategy. Vol II: Corporate Strategy. Oxford: Oxford University Press.

Gates, S., \& Very, P. (2003). Measuring Performance during M\&A Integration. Long Range Planning, 36, 167-185.

Habeck, M., Kröger, F., \& Träm, M. (2000). After the Merger Seven Rules for Successful Post-Merger Integration. Pearson Education Limited.

Haspeslagh, \& Jemison. (1991). In Fanlkner D., \& Cambell A. (2003). The Oxford Handbook of Strategy. Vol II: Corporate Strategy. Oxford: Oxford University Press.

Harbison, R. J., Viscio, J. A., \& Asin, T.A. (1999). Making Acquisitions Work: Capturing Value after the Deal. Fourth in a Series of Viewpoints on Alliances, Booz Allen \& Hamilton Inc., 1-20. Retrieved April, 242009 from http://www. boozallen.com/media/file/33886.pdf.

Homburg, C., \& Bucerius, M. (2005). A Marketing Perspective on Mergers and Acquisitions: How Marketing Integration affects Postmerger Performance. The Journal of Marketing, 69(1), 95-113.

Homburg, C., \& Bucerius, M. (2006). Is speed of integration really a success factor of mergers and acquisitions? An analysis of role of internal and external relatedness. Strategic Management Journal, 27(4), 347-367.

Kelly, J., Cook, C., \& Spitzer, D. (1999). Mergers \& Acquisitions: Global Research Report. KPMG, 1-21. Retrieved March 12, 2009 from http://people.stern.nyu.edu/adamodar/pdfiles/eqnotes/ KPMGM\&A.pdf.

Kimberly, E., \& Lamont, B. (2004). “Ideal"acquisition integration approaches in related acquisitions of equals: a test of longheld beliefs. Advances in Mergers and Acquisitions, 3, 81-102.

Larsson, R., \& Finkelstein, S. (1999). Integrating Strategic, Organizational, and Human Resource Perspectives on Mergers and Acquisitions: A Case Survey of Synergy Realization. Organization Science, 10(1), 1-26.

Marks, M. L., \& Mirvis, P. H. (1986). The Merger Syndrome, Psychology Today. In A. Risberg, (2006). Mergers and acquisition A Critical Reader. Routledge Taylor \& Francis Group.

Marks, M. L., \& Mirvis, P. H. (2001). Making mergers and acquisitions work: Strategic and psychological preparation. The Academy of Management Executive, 15(2), 80- 92.

Nahavandi, A., \& Malekzadeh, A. (1988). Acculturation in Mergers and Acquisitions. The Academy of Management Review, 13(1), 79-90. 
Nemanich, L., \& Vera, D. (2009). Transformational leadership and ambidexterity in the context of an acquisition. The Leadership Quarterly, 20, 19-33.

Pablo, A. (1994). Determinants of acquisition integration level: a decision-making perspective. Academy of Management Journal, 37(4), 803-836.

Pitkethly, R., Faulkner, D., \& Child, J. (2003). Integrating Acquisitions. Advances in Mergers and Acquisitions, 2, 27-57.

PricewaterhouseCoopers. (2000). Speed Makes the Difference - A Survey of Mergers and Acquisitions. PricewaterhouseCoopers LLP. Retrieved March 10, 2011, from http://www.sysedv.tuberlin.de/intranet/kc-kb.nsf/bc64cc33c3daf5fec1256979005 bc026/29CC7F0767AECFD9C1256CDA00354346/\$File/PWCM\&A2.pdf?OpenElement.

Schweiger, D. M., \& DeNisi A. S. (1991). Communication with Employees Following a Merger: A Longitudinal Field Experiment. In Risberg, A. (2006). Mergers and Acquisitions - A Critical Reader, Routledge Taylor \& Francis Group.
Schweizer, L., \& Patzelt, H. (2012). Employee commitment in the post-acquisition integration process: The effect of integration speed and leadership. Scandinavian Journal of Management, 28(4), 298-310.

Shrivastava, P. (1986). Post-merger integration. Journal of Business Strategy, 7(1), 65-76.

Teerikangas, S. (2006). Silent Forces in Cross-Border Acquisitions - An Integrative Perspective on Post-Acquisition Integration. Unpublished doctoral dissertation, Helsinki University of Technology Institute of Strategy and International Business. Retrieved October 10, 2010 from https://aaltodoc. aalto.fi/bitstream/handle/123456789/2691/isbn9512280930. pdf?sequence $=1$.

Wyman, O., Kautzsch, T., Thormählen, H., \& Vratimos, E. (2008). Post-merger integration - A tailored approach to sustainable transaction success. 1-16. Retrieved March 5, 2011, from www.oliverwyman.com/ow/pdf.../Post_Merger_ Integration_en.pdf.

Received on $4^{\text {th }}$ July 2012, after one revision, accepted for publication on $12^{\text {th }}$ December 2012

Sladjana Savovic is a teaching assistant at the Faculty of Economics, University of Kragujevac, Serbia, teaching an Enterprise Economics course. She received her MSc degree from the Faculty of Economics - University of Kragujevac. The main areas of her research interests are: market for corporate control, post-acquisition integration, corporate restructuring. 


\title{
ZNAČAJ POSTAKVIZICIONE INTEGRACIJE ZA KREIRANJE VREDNOSTI I USPEH MERDŽERA I AKVIZICIJA
}

\author{
Slađana Savović* \\ Ekonomski fakultet Univerziteta u Kragujevcu
}

\begin{abstract}
Preduzeća se često opredeljuju za merdžere i akvizicije kako bi pristupila novim tržištima, uvela nove proizvode, proširila bazu znanja, poboljšala konkurentsku prednost. Uspeh merdžera i akvizicija predstavlja kompleksan upravljački izazov, budući da je veliki broj ovih transakcija neuspešan u kreiranju vrednosti za akcionare. Postakviziciona integracija predstavlja najizazovniju fazu u kojoj dolazi do kreiranja vrednosti, ali u kojoj se mogu javiti i brojni integracioni problemi. U radu se kao faktori uspeha postakvizicione integracije preduzeća ističu: integraciona strategija, sastav integracionog tima, komuniciranje, brzina integracije, ujednačena merila. Posebno se ukazuje na značaj brzine integracije kao faktora uspeha postakvizicione integracije preduzeća.
\end{abstract}

Ključne reči: postakviziciona integracija, osnovni faktori uspeha, brzina integracije, uspeh merdžera i akvizicija

\section{JEL Classification: G34, L25}

\section{UVOD}

Pristupanje procesima akvizicija odražava nastojanje preduzeća da osvoje nova tržišta, pristupe tehnologijama, povećaju efikasnost putem iskorišćavanja ekonomija obima, ekonomije širine ili ekonomije učenja. U isto vreme, akvizicije su kompleksan fenomen i uslovi pod kojima unapređuju ili uništavaju vrednost preduzeća još uvek ostaju nejasni uprkos brojnim istraživanjima iz oblasti finansija i menadžmenta. $U$ istraživanjima konsultantskih i revizorskih firmi i u naučnim istraživanjima dominira zaključak da se stopa neuspeha

\footnotetext{
* Korespondencija: S. Savović, Ekonomski fakultet Univerziteta u Kragujevcu, Đ. Pucara 3, 34000 Kragujevac, Srbija; e-mail: ssladjana@kg.ac.rs
}

transakcija kreće u proseku oko $50 \%$, odnosno, da se jedno od dva preuzimanja može smatrati uspešnim (Kelly et al, 1999; Adolph et al, 2001; Marks \& Mirvis, 2001). Otuda je $u$ fokusu istraživanja, na teorijskom i praktičnom nivou, identifikovanje načina za povećanje stope uspeha merdžera i akvizicija.

Istraživanja o merdžerima i akvizicijama mogu se grupisati $u$ četiri glavne kategorije, odnosno, perspektive: finansijska, strategijska, organizaciona i procesna (Birkinshaw, Bresman \& Hakanson, 2000). Kreiranje vrednosti nastaje u periodu koji sledi nakon preuzimanja, zbog čega je u novije vreme pažnja istraživača usmerena na proces postakvizicione integracije. Istraživački okvir za proučavanje postakvizicione integracije nalazi se $u$ organizacionoj 
i procesnoj perspektivi. Sa stanovišta organizacione perspektive, istraživanja obuhvataju organizaciono ponašanje $u$ procesima preuzimanja (Marks \& Mirvis, 2001), dok se u procesnoj perspektivi potencijalni problem razmatra menadžment promenama prilikom integracije (Birkinshaw, Bresman \& Hakanson, 2000; Haspeslagh \& Jemison, 1991). Teorija procesa odlučivanja, korišćena u osvetljavanju integracionog procesa, ukazuje na to da top menadžment kreira strukturalni i strategijski kontekst koji oblikuje ponašanje članova organizacije na različitim nivoima. Proučavajući faktore uspeha, veliki broj autora došao je do zaključka da je upravljanje različitim elementima integracionog procesa ključna determinanta postakvizicionih ishoda. Menadžment za rešavanje problema integracionog procesa može datipreduzećima koja vrše preuzimanja konkurentsku prednost i omogućiti im razvijanje uspešne strategije rasta putem akvizicije. Uspešna postakviziciona integracija zavisi i od toga da li će liderski tim prepoznati prave trenutke $\mathrm{u}$ integracionom procesu za odlučno preduzimanje akcija.

Cilj rada je pokazati kakve mogućnosti postoje za kreiranje vrednosti $\mathrm{u}$ okviru procesa postakvizicione integracije preduzeća, identifikovati faktore uspeha i oceniti uticaj brzine integracije na efikasnost datog procesa, kao i na ukupni uspeh akvizicija. Shodno postavljenom cilju istraživanja, rad se zasniva na sledećoj ključnoj hipotezi: ako se vrednost kreira nakon akvizicije, onda brzina postakvizicione integracije ima veliki uticaj na efikasnost integracije i uspeh akvizicije. U radu će biti primenjena kvalitativna metodologija, utemeljena na proučavanju i deskriptivnoj analizi istraživačkog problema. Istraživanjem ce biti konsultovana relevantna literatura zasnovana na teorijskim uopštavanjima i praktičnim iskustvima autora koji su se bavili predmetnom problematikom. Polazeći od relevantne literature, analiziraće se proces postakvizicione integracije preduzeća, sagledaće se kakve mogućnosti postoje za kreiranje vrednosti i kakvi se problemi mogu javiti u okviru datog procesa, identifikovaće se faktori uspeha postakvizicione integracije preduzeća. Posebno će se analizirati brzina integracije kao faktor uspeha, ukazaće se na prednosti, ali i na nedostatke brzine integracije, kako bi se došlo do odgovora na pitanje kakav može biti ukupni efekat brzine na efikasnost postakvizicione integracije i ukupni uspeh akvizicije.

\section{POSTAKVIZICIONA INTEGRACIJA PREDUZEĆA: DEFINICIJA I NIVOI INTEGRACIJE}

Postakviziciona integracija obično se posmatra kao dugotrajan i otvoren proces, koji započinje od trenutka preuzimanja (potpisivanja sporazuma) i traje nekoliko godina nakon toga. Kao takav, uključuje aktivnosti koje treba da obezbede efektivno i efikasno upravljanje organizacionim aktivnostima i resursima $\mathrm{u}$ pravcu ostvarivanja nekog skupa zajedničkih organizacionih ciljeva. Postakviziciona integracija može se posmatrati kao evolutivni proces $u$ organizaciji, kao integrisanje i kombinovanje organizacija i kao serija upravljačkih inicijativa i planiranih aktivnosti, koje se odnose na pitanja poput određivanja nivoa integracije, autonomije koja će se dodeliti preuzetom preduzeću, brzine integracije i sl.

U procesu akvizicije prethodno nezavisnih preduzeća nastaje hibridna organizacija u kojoj kreiranje vrednosti zavisi od upravljanja međuzavisnostima. Pablo (1994) definiše integraciju kao promene $u$ aranžmanima funkcionalnih aktivnosti, organizacionim strukturama i sistemima, kao i kulturama kombinovanih organizacija kako bi se olakšala njihova konsolidacija $\mathrm{u}$ okviru jedne funkcionalne celine. Lindgren (prema Teerikangas, 2006) definiše integraciju kao proces koji se bavi administrativnim, organizacionim (organizaciona struktura, sistemi nagrađivanja i komuniciranja, finansijski sistemi), socijalnim (kulturološki sistemi) i operativnim (proizvodnja, marketing, R\&D) sistemima. Radi se o multidimenzionalnom procesu tokom koga menadžeri treba da omoguće da sva odeljenja skladno funkcionišu u okviru kombinovanog entiteta.

Prema Shrivastava-i (1986), primarni problem efikasnog upravljanja procesom preuzimanja leži u integraciji dva preduzeća $u$ jedan entitet. Postakviziciona integracija može se izvršiti na tri različita nivoa u zavisnosti od situacije preuzimanja. Prvinivoje proceduralna (pravna i računovodstvena integracija), drugi nivo je fizička (integracija proizvodnih linija i tehnologije) i treći nivo 
upravljačka i socio-kulturološka integracija (promene organizacione strukture, razvoj organizacione kulture, selekcija menadžera). Što su preduzeća veća, teže je izvršiti integraciju, zbog velikog broja jedinica koje treba koordinirati. Ovaj autor ističe da je za dugoročni uspeh ključno koliko su dobro integrisana poslovanja dva preduzeća. S druge strane, ima autora (Pitkethly, et al, 2003, 33) koji navode da nije bitno koliko su dobro biznisi integrisani, već da je integracija izvršena na adekvatnom nivou. Nivo integracije se može rangirati od niskog do visokog: preuzeto preduzeće može ostati samostalno nakon preuzimanja (neintegrisana preduzeća), preduzeće koje je izvršilo preuzimanje može se prilagoditi preuzetom preduzeću (delimično integrisana preduzeća) i preduzeća mogu da se spoje $\mathrm{u}$ okviru jedne organizacije (potpuno integrisana preduzeća) (Slika 1). izvršilo preuzimanje, kao i kompletnu strukturalnu i kulturološku apsorpciju preuzetog preduzeća (Pablo, 1994).

Nastojeći da identifikuju "idealne" integracione pristupe, Kimberly \& Lamont (2004), polaze od radova Nahavandi i Malekzadeh (1988), Haspeslagh \& Jemison (1991) i Marks \& Mirvis (1998). Nahavandi \& Malekzadeh (1988) proučavali su proces usklađivanja kultura u okviru postakvizicione integracije i identifikovali različite modele koji su zasnovani na dvema glavnim dimenzijama - stepen povezanosti dva preduzeća i stepen tolerancije većeg broja kultura od strane preduzeća koje vrši preuzimanje. Ovi autori daju kratak opis načina usklađivanja kultura - razdvajanje, asimilacija, integracija i gubljenje kultura. Haspeslagh i Jemison (1991) razvili su okvir koji ukazuje na to

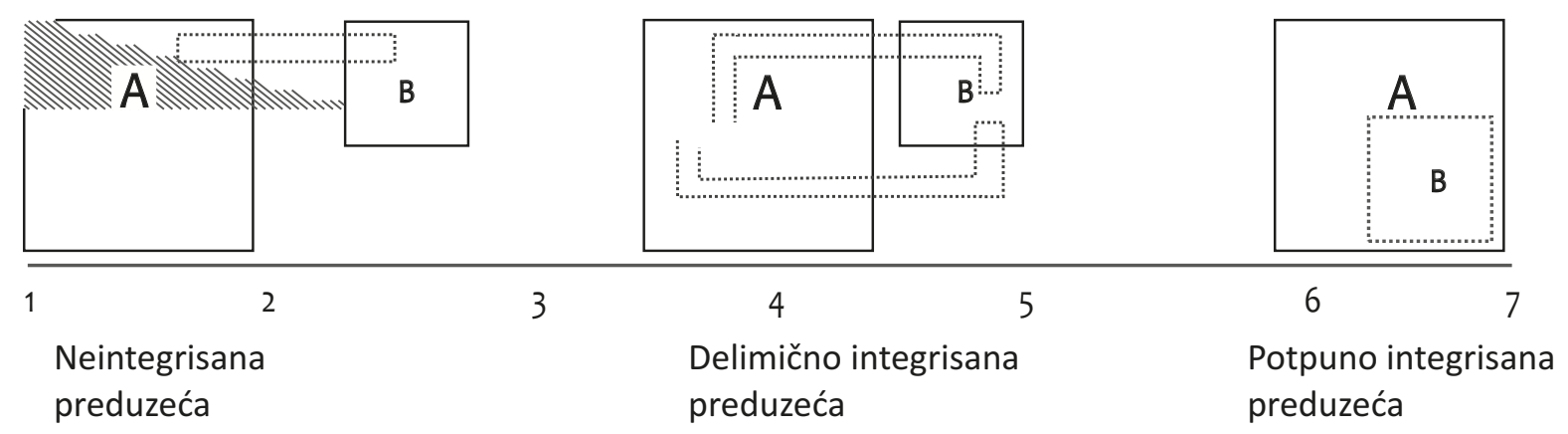

Slika 1 Spektar integracije

Izvor: Pitkethly et al, 2003, 33

Nizak nivo integracije je takav nivo u kome su tehničke i administrativne promene ograničene na podelu finansijskog rizika i resursa $i$ na standardizaciju osnovnih upravljačkih sistema i procesa kako bi se olakšalo komuniciranje. Umeren nivo integracije podrazumeva veće promene $\mathrm{u}$ lancu vrednosti, kao i podelu i razmenu fizičkih i resursa zasnovanih na znanju. Administrativne promene na ovom nivou mogu uključivati selektivne modifikacije $\mathrm{u}$ odnosima izveštavanja i delegiranju autoriteta. $\mathrm{Na}$ najvišem nivou, integracija uključuje deljenje svih tipova resursa, usvajanje sistema funkcionisanja, sistema kontrole i planiranja, procedura preduzeća koje je da će adekvatni oblici integracije zavisiti od odnosa između dva ključna zahteva: stepena strategijske međuzavisnosti dve kompanije i potrebe ostvarivanja organizacione autonomije. Polazeći od ova dva zahteva, mogu se navesti četiri oblika integracije: apsorpcija, simbioza, zaštita i holding (Fanlkner \& Cambell, 2003, 109-112). Marks i Mirvis (Kimberly \& Lamont, 2004) diskutuju o nekoliko glavnih načina na koji preduzeća kombinuju svoje operacije nakon akvizicije. Koristeći stepen postakvizicionih promena u oba preduzeća, respektivno, kao osnovu svoje klasifikacione šeme, ovi autori identifikuju i opisuju organizacione atribute neophodne za uspešno upravljanje glavnim 
integracionim pristupima - apsorpcija, reverzni merdžer/asimilacija, zaštita (očuvanje), najbolje od oba i transformacija. Slika 2 prikazuje preklapanje različitih integracionih pristupa.

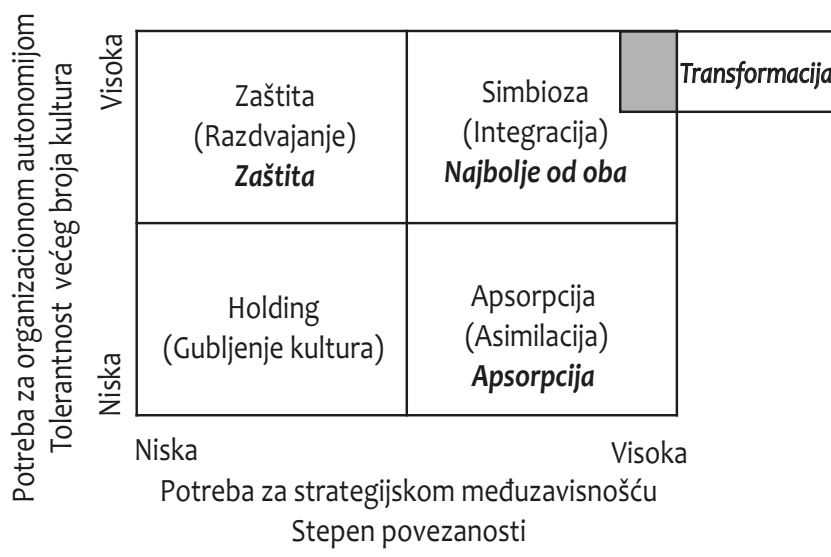

Slika 2 Integracioni pristupi

Izvor: Kimberly \& Lamont, 2004

Integracija putem apsorpcije predlaže se kada postoji velika potreba za strategijskom međuzavisnošću i mala potreba za organizacionom autonomijom, a kao cilj postavlja ostvarivanje potpune konsolidacije poslovanja, strukture i kulture dva preduzeća. Budući da ovaj pristup obično uključuje značajan stepen promena u preuzetom preduzeću, neophodno je da se izvrši na unapred definisan, konzistentan i brz način, kako bi se minimizirali mogući poremećaji i neizvesnost koje sa sobom može doneti postakvizicioni integracioni proces.

Integracija putem simbioze znači da preduzeće koje vrši preuzimanje pokušava da ostvari balans između dva poslovna modela tako da transferom strategijskih sposobnosti ne ugrozi organizacionu autonomiju preuzetog preduzeća. Pristup simbioze uključuje period inicijalne zaštite (očuvanja postojećeg stanja), a zatim, period postepenog mešanja (spajanja, kombinovanja) najboljih praksi iz oba preduzeća. Ovaj proces integracije zahteva od oba preduzeća da prođu određeni stepen promena kako bi se stvorilo kombinovano preduzeće koje odražava suštinsku kompetentnost i vodeće prakse oba preduzeća (Kimberly \& Lamont, 2004, 81-102).

Integracija uz zaštitu predlaže se kada postoji potreba da preuzeto preduzeće ima visok stepen autonomije i kada postoji nizak zahtev za strategijskom međuzavisnošću dva kombinovana poslovanja. Kod ovog oblika integracije, novo preuzeto preduzeće nastavlja da posluje kao samostalni deo. U suštini, pristup uključuje jako malo promena kod preduzeća koja učestvuju u transakciji, s obzirom na to da je primarni pokretač ostvarivanja postakvizicionog uspeha sposobnost da se očuvaju netaknute one strategijske sposobnosti koje su dobijene od preuzetog preduzeća.

Holding se odnosi na situaciju u kojoj preduzeće koje vrši preuzimanje deluje $\mathrm{u}$ osnovi kao holding kompanija koja nema nameru da izvrši integraciju dva preduzeća. Ovaj pristup podrazumeva postojanje niskog stepena strategijske međuzavisnosti, pri čemu se preuzetom preduzeću ne ostavlja visok stepen autonomije. Ponekad je teško u praksi napraviti jasnu razliku između kategorija holding i zaštite. Međutim, u svom radu Pitkethly i ostali (2003) navode da Angwin stavlja akcenat na dve kategorije praveći razliku između holding kategorije, gde preduzeće koje vrši preuzimanje pokušava da izvrši preokret, ali bez bilo kog stepena integracije, za razliku od pristupa očuvanja gde preuzeta kompanija ostaje neintegrisana, ali u cilju nastavljanja ostvarivanja visokih profita.

Dok je kod simbioze neophodan određeni stepen promena koje oba preduzeća treba da izvrše, kada se usvoje najbolje prakse, ponekad proces integracije uključuje veoma značajne, fundamentalne promene $\mathrm{u}$ organizacionoj kulturi i operativnim praksama oba preduzeća. U ovim slučajevima gde se oba preduzeća rasformiraju kao deo integracionih napora, način kombinovanja operacija poznat je pod nazivom transformacioni pristup. Ovaj pristup zahteva od novokombinovanog preduzeća da se iznova formira, kreirajući novu organizaciju, skup vrednosti i način poslovanja, umesto da kombinuje najbolje elemente oba originalna preduzeća.

Koji će integracioni pristup preduzeća izabrati zavisi od tipa preuzimanja i karakteristika poslovanja. Treba imati u vidu da svaki integracioni pristup ima svoje 
posebne prepreke. Na primer, apsorpcija preuzetog preduzeća mogla bi da izazove rezistentnost zaposlenih na promene i napuštanje organizacije. Kod simbioze, kreiranje nove organizacije i selekcija menadžera na određene pozicije $u$ okviru nove strukture može uništiti kooperativnu atmosferu dok je kod pristupa zaštite, specifičan izazov očuvanje jasnih granica između preduzeća.

\section{MOGUĆNOSTI KREIRANJA VREDNOSTI I PROBLEMI TOKOM POSTAKVIZICIONE INTEGRACIJE PREDUZEĆA}

Veliki broj autora (Datta, 1991; Pablo, 1994; Larsson \& Finkelstein, 1999) isticao je da se potencijal strategijske kombinacije ne realizuje automatski, i da stepen realizacije sinergije zavisi od toga kako se novom organizacijom upravlja nakon završetka transakcije preuzimanja. Tako, Larsson \& Finkelstein (1999), definišući integraciju kao stepen interakcije i koordinacije između dva preduzeća koja su uključena $u$ procese merdžera ili akvizicija, ističu da ona ima veliki značaj u realizaciji potencijalne sinergije, jer loše sprovedena interakcija i koordinacija neće dovesti do ostvarivanja zajedničkih koristi.

Postakviziciona integracija je motor organizacionih promena i razvoja, i igra ključnu ulogu u ukupnoj strategiji obnavljanja. Uključuje postakvizicionu rekonfiguraciju, pregrupisavanje i odstranjivanje materijalne imovine i nematerijalnih resursa oba preduzeća (Chakrabarti \& Mitchell, 2004). Radi se o procesu adaptacije u okviru kojeg preduzeće koje je izvršilo preuzimanje i preuzeto preduzeće prenose sposobnosti i rade na ostvarivanju ciljeva preuzimanja.

Postakviziciona integracija se može opisati kao proces koji obuhvata najmanje dve faze - "prvih sto dana" i faza "transfera sposobnosti". Faza "prvih sto dana" počinje odmah nakon realizacije preuzimanja i glavni ciljevi ove faze su očuvanje impulsa oba preduzeća i kreiranje povoljne klime za iskorišćavanje sinergija. Prvih sto dana i nedelje nakon objave preuzimanja karakteriše neizvesnost. Kod velikog broja zaposlenih prisutan je strah usled neizvesnosti i neophodno ih je razuveriti i obezbediti njihovu posvećenost novim projektima. Kada se kreira pogodna atmosfera, preduzeće koje je izvršilo preuzimanje može da se fokusira na fazu transfera sposobnosti. Cilj ove faze je iskoristiti sinergije kako bi se realizovala očekivana vrednost od transakcije (Gates \& Very, 2003, 165-185).

Integracija preduzeća koje je izvršilo preuzimanje i preuzetog preduzeća u pravnom, strukturalnom i kulturološkom smislu je važan faktor kreiranja vrednosti i uspeha merdžera i akvizicija. Sastoji se od interakcija koje čine okruženje za transfer sposobnosti koje mogu kreirati vrednost i omogućiti realizaciju svrhe merdžera i akvizicija. Haspeslagh i Jemison (1991) prave razliku između različitih tipova transfera sposobnosti, raspodela resursa, transfera znanja (ili veština), transfera upravljačkih veština, koji dovode do poboljšanja konkurentske prednosti.

Raspodelom resursa se određena operativna sredstva dva preduzeća kombinuju i racionalizuju, dovodeći do smanjenja troškova usled ekonomija obima i širine. Raspodela resursa se generalno bazira na postojanju sličnosti između dva preduzeća i često se primenjuje kod preuzimanja unutar grana.

Transferom znanja vrši se prenos znanja koje uvećava vrednost, kao što je proizvodna tehnologija, marketing know-how ili veštine finansijske kontrole. Dodatna vrednost može se stvoriti putem rezultirajućeg sniženja troškova ili poboljšanja tržišne pozicije koji dovode do uvećanja prihoda i/ili marži.

Treći izvor vrednosti bazira se na transferu strategijske logike za upravljanje promenama kod preuzetog preduzeća. Novi menadžment tim često donosi poboljšanje konkurentske pozicije ovog preduzeća, doprinoseći time povećanju njegovih prihoda. Ovaj tim može doprineti i ostvarivanju ušteda u troškovima ukoliko se raniji tim ponašao rasipnički (Fanlkner \& Cambell, 2003, 95-117).

Naglašavajući važnost integracije za kreiranje vrednosti i za uspeh merdžera i akvizicija, autori se slažu da postoje i brojni integracioni problemi koji, ukoliko se njima adekvatno ne upravlja, mogu sprečiti ostvarivanje sinergija. Integracioni problemi mogu nastati usled rezistentnosti zaposlenih i nekompatibilnosti kultura. Postakvizicione promene često uključuju redukciju 
radne snage $\mathrm{i}$ strukturalno redizajniranje $\mathrm{u}$ cilju smanjenja troškova i smanjivanja redundantnosti. Ovakve organizacione i personalne promene kreiraju atmosferu psihološke nesigurnosti i neizvesnosti za zaposlene. U takvim uslovima dolazi do sve veće diferencijacije unutar grupa, formiranja scenarija dobitnika-gubitnika i opšteg nepoverenja. Nedostatak predvidivosti i slaba upoznatost zaposlenih sa stanjem u preduzeću dovodi do konfuzije i uznemirenosti (Elsass \& Veiga, 1994, 95-105). Takve organizacione promene imaju naročito ozbiljan uticaj na zaposlene koji smatraju da nemaju kontrolu nad snagama promena. Takvi zaposleni će, verovatno, osećati veće smanjenje u kontroli na poslu, osećati bespomoćnost, psihološki se udaljiti od posla koji rade, odnosno, pokazivati rezistentnost ka promenama (Chakrabarti \& Mitchell, 2004).

Larsson i Finkelstein (1999) otkrivaju da rezistentnost zaposlenih umanjuje iskorišćavanje mogućih sinergija. Oni definišu rezistentnost kao pojedinačno i kolektivno suprotstavljanje zaposlenih kombinaciji i integraciji, što negativno utiče na performanse merdžera i akvizicija. Suprotstavljanje može biti aktivno (dobrovoljno napuštanje organizacije, sabotaža) i pasivno (izostajanje sa posla, neposlušnost) i očekuje se da će značajno umanjiti realizaciju sinergije tokom procesa integracije. Birkinshaw i ostali (2000) zaključuju da loše upravljanje ljudskim resursima štetno utiče na ukupni napredak integracione faze. Stres, nesigurnost, glasine oko merdžera i akvizicija imaju posledice na finansijske i operativne performanse preduzeća.

Kulturološka nekompatibilnost često se navodi kao izvor postakvizicionih problema (Nahavandi \& Malekzadeh, 1988), koji mogu dovesti do neiskorišćavanja sinergija. Neki empirijski podaci ukazuju na to da veće kulturološke razlike vode većim integracionim problemima i otuda nižim postakvizicionim performansama (Datta, 1991). S druge strane, razvijena korporativna kultura kod preduzeća koje vrši preuzimanje može pozitivno uticati na performanse, ukoliko se ona efikasno transferiše ka preuzetom preduzeću (Chakrabarti \& Mitchell, 2004).

Integracioni problemi mogu biti ozbiljna prepreka uspehu akvizicija, ali se njima može upravljati. Značaj$\mathrm{nu}$ ulogu $\mathrm{u}$ upravljanju procesom postakvizicione integracije i prevazilaženju mogućih problema imaju transformacioni lideri koji treba da vode kritičnu masu zaposlenih kroz period velike neizvesnosti, da obezbede kontinuitet operativnog delovanja i da nauče zaposlene novom obrascu ponašanja (Babić \& Savović, 2009). Transformaciono liderstvo je efektivnije od transakcionog liderstva u situacijama neizvesnosti ili krize, kao što je slučaj sa procesom integracije. Transformacioni lideri ohrabruju sledbenike da teže zajedničkim ciljevima i interesima. Na taj način razvija se pozitivan interpersonalni odnos članova tima i nastaje mikrokontekst $\mathrm{u}$ kome zaposleni dele postojeće znanje i kreiraju novo. (Nemanich \& Vera, 2009).

Transformacioni lideri imaju sposobnosti i veštine da motivišu zaposlene na nov način razmišljanja, rušeći postojeće paradigme i kreirajući nove. Zadatak ovih lidera je da komuniciraju dobro artikulisanu viziju, stvaraju osećaj pripadnosti i podstiču zaposlene na prilagođavanje promenama. Od presudnog značaja za uspešnu asimilaciju grupa ili stvaranje novih grupa je sposobnost vođenja zaposlenih, uspostavljanje novog poslovnog identiteta, koji omogućava usvajanje zajedničke vizije i, što je najvažnije, razvijanje osećaja međupovezanosti i pripadnosti. Komunicirajući zajedničku viziju, transformacioni lideri olakšavaju zaposlenima da shvate promene koje se dešavaju $\mathrm{u}$ njihovom poslovnom okruženju i da adekvatno odgovore na njih. Ohrabrivanje zaposlenih da učestvuju u procesima redizajniranja poslova preporučuje se kao koristan način za smanjivanje moguće rezistentnosti tokom tranzicije. Pored toga, komuniciranje sa zaposlenima o anticipiranim efektima promena doprinosi smanjivanju uznemirenosti i zabrinutosti (Schweiger \& DeNisi, 1991) i povećanju njihove posvećenosti procesu integracije (Schweizer \& Patzelt, 2012).

\section{OSNOVNI FAKTORI USPEHA POSTAKVIZICIONE INTEGRACIJE PREDUZEĆA}

Važan deo istraživanja akvizicija usmeren je na proučavanje procesa postakvizicione integracije preduzeća. Ovo se bazira na premisi da "se vrednost kreira nakon akvizicije" i da, ukoliko se na pravi 
način upravlja postakvizicionim aktivnostima, mogu se povećati šanse za uspeh akvizicija. Veliki broj istraživača, konsultantskih firmi, stručnjaka iz ove oblasti pokušava da odgovori na pitanje koji faktori determinišu uspeh postakvizicione integracije.

De Noble i ostali $(1997,51-59)$ navode sledeće faktore: imati jasnu i preciznu viziju pre okončanja transakcije preuzimanja, formiranje unakrsno obogaćenog menadžment tima, kontinuirani fokus na zaposlene, upravljanje kulturološkim razlikama, povezanost strategije i strukture, brzina implementacije. Studija Harbison-a i ostalih (1999) omogućila je razvijanje vrednosnog okvira, sastavljenog od tri elementa: vizija, arhitektura i liderstvo, koji su od suštinskog značaja za uspeh postakvizicione integracije (Tabela 1). Da bi se kompanije uspešno integrisale, moraju da dobro upoznaju ova tri suštinska elementa. Ukoliko se ne poznaje vizija novog preduzeća, tada tom preduzeću nedostaje fokus i smer i neće znati kako da kreira vrednost za nove kupce, na čemu se bazira njegova konkurentska prednost, i kako da ostvari svoje ciljeve. Bez dobro strukturiranog procesa integracije, odnosno, prave arhitekture, $\mathrm{u}$ potpunosti vlada haos $\mathrm{u}$ novom preduzeću. Ključne odluke se odnose na određivanje delova poslovanja koje treba integrisati i brzine sprovođenja integracije. Na kraju, ukoliko ne postoji

Tabela 1 Tri elementa neophodna za promene

\begin{tabular}{|c|c|c|c|}
\hline Vizija & Arhitektura & Liderstvo & Ishod \\
\hline$\bullet$ & $\bullet$ & $\bullet$ & $\begin{array}{l}\text { Uspešna postakvizici- } \\
\text { ona integracija }\end{array}$ \\
\hline$\bullet$ & $\bullet$ & $\mathrm{O}$ & $\begin{array}{l}\text { Ne dešavaju se } \\
\text { potrebne promene } \\
\text { u kompanijama ili na } \\
\text { svim nivoima }\end{array}$ \\
\hline 0 & $\bullet$ & $\bullet$ & $\begin{array}{l}\text { Nema fokusa: Novom } \\
\text { preduzeću nedostaje } \\
\text { usmerenje }\end{array}$ \\
\hline$\bullet$ & O & $\bullet$ & $\begin{array}{l}\text { Haos: Ne postoji pro- } \\
\text { ces bitan za integraciju }\end{array}$ \\
\hline$\bullet$ & $\mathrm{O}$ & $\mathrm{O}$ & Teorijska upotreba \\
\hline O & $\bullet$ & $\mathrm{O}$ & Birokratija \\
\hline 0 & O & 0 & Prazna harizma \\
\hline
\end{tabular}

Izvor: Harbison et al, 1999, 8 efikasno liderstvo, neće doći do potrebnih promena $\mathrm{u}$ oba preduzeća na svim nivoima. Istraživanje je pokazalo da neuspeh $\mathrm{u}$ određivanju sva tri elementa može dovesti do uništavanja vrednosti. Da bi preduzeće uspešno sprovelo proces postakvizicione integracije, neophodno je da kreira novu viziju za nov entitet, planirajući detalje od početka, identifikujući izvore vrednosti i načine njihovog usvajanja, shvatajući značaj strategijskog liderstva koje će pomoći u sprovođenju neizbežnih promena i pokrenuti sposobnosti novog preduzeća ka ostvarivanju maksimalnog profita i rasta (Harbison et al, 1999).

Adolph i ostali (2001) navode četiri principa koji su ključni za uspeh postakvizicione integracije: komuniciranje vizije za kreiranje vrednosti, definisanje pravih trenutaka za ostvarivanje eksplicitnih izbora i pravljenje kompromisa (određivanje karaktera i brzine procesa integracije), simultana izvršenja na osnovu konkurisanja kritičnim imperativima i rigorozna primena procesa integracionog planiranja.

Epstein (2004) ističe da postoji pet pokretača uspeha postakvizicione integracije: koherentna integraciona strategija, ozbiljni integracioni tim, komuniciranje, brzina integracije, ujednačeno merenje (Tabela 2). Neuspeh bilo kog od ovih pet faktora može sprečiti ostvarenje ciljeva akvizicije. Dok neki mogu biti lako kontrolisani krozoprezno dizajniranjeiimplementaciju, ostali su mnogo izazovniji usled brojnih eksternih snaga.

Wyman i ostali (2008, 1-16), kao ključne pokretače uspeha integracije ističu: vrste sinergija koje treba ostvariti, brzinu, stepen integracije, početnu tačka integracionog posla, sastav integracionog tima, pristup u donošenju ključnih odluka, stepen komuniciranja i upravljanje promenama.

Agrawal i ostali (2011), istražuju sledeće faktore uspeha integracije: praćenje sinergije, definisanje i upravljanje rokovima, budžetiranje troškova integracije, planiranje integracije, postavljanje integracionog menadžera, formiranje i implementacija strategije komuniciranja, upravljanje kulturološkim pitanjima, uključenost različitih ključnih ljudi u upravljanju integracijom.

U nastojanju da dođu do odgovora na pitanje šta determiniše uspeh postakvizicione integracije, istraživači su otkrivali različite faktore. Sumirajući rezultate empirijskih istraživanja i relevantne literature, 
Tabela 2 Pet pokretača uspeha kod korporativne integracije

\begin{tabular}{|c|c|c|c|}
\hline & Merdžer & Akvizicija & Konglomerat \\
\hline $\begin{array}{l}\text { Integraciona } \\
\text { strategija }\end{array}$ & $\begin{array}{l}\text { Promovisanje „,merdžera jednakih“. } \\
\text { Meritokratske odluke (odluke zasno- } \\
\text { vane isključivo na zasluzi). } \\
\text { Prakse izabrane bez uvažavanja pre- } \\
\text { thodnih praksi kompanija. }\end{array}$ & $\begin{array}{l}\text { Stvaranje utiska da je preuzeta kom- } \\
\text { panija bila „uvek tu“. } \\
\text { Preuzeta kompanija preuzima praksu } \\
\text { kompanije koja je izvršila preuzi- } \\
\text { manje. }\end{array}$ & $\begin{array}{l}\text { Nema suštinskih promena u novoj } \\
\text { kompaniji. } \\
\text { Asimilacija nove kompanije u } \\
\text { određenim ključnim oblastima i } \\
\text { dodavanje određenih propuštenih } \\
\text { funkcija. }\end{array}$ \\
\hline $\begin{array}{l}\text { Integracioni } \\
\text { tim }\end{array}$ & $\begin{array}{l}\text { Tim koji ovom poslu posvećuje } \\
\text { puno radno vreme, ima na raspola- } \\
\text { ganju obimne resurse i koji je podržan } \\
\text { učešćem senior menadžmenta. } \\
\text { Jednako učešće obe kompanije. }\end{array}$ & $\begin{array}{l}\text { Mali, odvojen tim sa obimnim resur- } \\
\text { sima i učešćem senior menadžmenta. } \\
\text { Zadržava se liderstvo nad preuzetom } \\
\text { kompanijom. }\end{array}$ & $\begin{array}{l}\text { Zadržava se liderstvo nad preuze- } \\
\text { tom kompanijom. } \\
\text { Menadžment obe kompanije } \\
\text { promoviše znanje. }\end{array}$ \\
\hline $\begin{array}{l}\text { Komunici- } \\
\text { ranje }\end{array}$ & $\begin{array}{l}\text { Kupci obe kompanije moraju razumeti } \\
\text { promene u poslovanju. } \\
\text { Zaposleni u obe kompanije moraju } \\
\text { razumeti nove uloge i mogućnosti. } \\
\text { Fokus na način usklađivanja kom- } \\
\text { panije. }\end{array}$ & $\begin{array}{l}\text { Kupci preuzete kompanije moraju } \\
\text { razumeti nove mogućnosti u poslo- } \\
\text { vanju. } \\
\text { Zaposleni preuzete kompanije moraju } \\
\text { razumeti nove uloge. } \\
\text { Fokus na način usklađivanja preuzete } \\
\text { kompanije sa poslovanjem kompanije } \\
\text { koja je izvršila preuzimanje. }\end{array}$ & $\begin{array}{l}\text { Nekoliko mogućnosti za kupce. } \\
\text { Matična kompanija mora da razume } \\
\text { kako nova kompanija funkcioniše i } \\
\text { nove sinergije. } \\
\text { Nova kompanija mora da razume } \\
\text { praksu i mogućnosti matične } \\
\text { kompanije. }\end{array}$ \\
\hline Brzina & $\begin{array}{l}\text { Brze odluke su od ključnog značaja } \\
\text { za ostvarenje strategijskih ciljeva i } \\
\text { promovisanje stabilnosti i smanjivanje } \\
\text { neizvesnosti u organizaciji. }\end{array}$ & $\begin{array}{l}\text { Brze odluke su od ključnog značaja } \\
\text { za ostvarenje strategijskih ciljeva i } \\
\text { promovisanje stabilnosti i smanjivanje } \\
\text { neizvesnosti u organizaciji. }\end{array}$ & $\begin{array}{l}\text { Brze odluke su, pre svega, važne } \\
\text { za smanjivanje neizvesnosti u } \\
\text { organizaciji. }\end{array}$ \\
\hline $\begin{array}{l}\text { Ujednačena } \\
\text { merila }\end{array}$ & $\begin{array}{l}\text { Balans između finansijskih i nefinansi- } \\
\text { jskih merila. } \\
\text { Težnja ka prihodnim i troškovnim } \\
\text { sinergijama. }\end{array}$ & $\begin{array}{l}\text { Fokus na to kako da preuzeta kom- } \\
\text { panija ostvari rast i reducira troškove. } \\
\text { Preuzeta kompanija usvaja sistem } \\
\text { merenja kompanije koja je izvršila } \\
\text { preuzimanje. }\end{array}$ & $\begin{array}{l}\text { Većina internih merenja ostaje ista } \\
\text { kod nove kompanije. } \\
\text { Uvode se nova merila kako bi se } \\
\text { asimilirala nova kompanija u okviru } \\
\text { matične kompanije. }\end{array}$ \\
\hline
\end{tabular}

Izvor: Epstein, 2004, 180

uočava se nesumnjiv značaj brzine integracije kao faktora uspeha.

\section{BRZINA KAO FAKTOR USPEHA POSTAKVIZICIONE INTEGRACIJE PREDUZEĆA}

Brzina integracije može se definisati kao vremenski interval neophodan za sprovođenje integracije sistema, struktura, aktivnosti i procesa dve kompanije. Postoje brojni razlozi zašto brzina može biti imperativ. Iz finansijske perspektive, vreme troši novac $i$, ukoliko se postakviziciona integracija brže kompletira, utoliko će se prinosi brže realizovati. Posmatrano iz bihejviorističke perspektive, brzina je važna zbog ublažavanja neizvesnosti koja postoji kod zaposlenih i kupaca. Brža integracija može skratiti vreme izlaganja zaposlenih neizvesnostima i smanjiti eksponencijalne efekte glasina. U slučaju brze postakvizicione integracije nema puno vremena da se glasine prošire na tržištu, što vodi smanjenju neizvesnosti za kupce. Ukoliko su odluke o postakvizicionoj integraciji, koje su relevantne za kupce, donete i implementirane brzo, kupci će znati šta da očekuju od preduzeća u pogledu ponude proizvoda, politike cena, strategije prodaje, kontakt osoba i sl. Pored toga, u poslovnoj praksi zajedničko je da preduzeća koja su konkurenti preduzeću koje vrši preuzimanje pokušavaju da povećaju neizvesnost 
kod kupaca kako bi ih preokrenuli i pridobili za sebe. Ovaj potencijalni izvor neizvesnosti za kupce može se smanjiti putem brze postakvizicione integracije. Iz perspektive organizacionih promena, povećanje brzine integracije može doneti koristi organizaciji $u$ vidu kraćeg vremena koje se posvećuje koordinaciji.

Brzinom integracije posebno su se bavili: Epstein (2004), Colombo i ostali (2007), Homburg i Bucerius $(2005,2006)$.

Epstein (2004) ukazuje na to da je brzina od suštinskog značaja za uspeh postakvizicione integracije i da strah i neodlučnost često mogu biti prepreka za brze akcije. Ovaj autor naglašava da se kompanije, koje se kreću suviše sporo u procesu integrisanja, suočavaju sa brojnim pretnjama, posebno $u$ pogledu dva ključna konstituenta (zaposleni i kupci). S jedne strane, zaposleni mogu zahtevati sporiji tempo, kao znak nesigurnosti, ili težiti odlasku u konkurentske firme, gde im se čini da je situacija stabilnija. Kupci, s druge strane, mogu osećati strah i nesigurnost i težiti konkurentskim proizvodima ukoliko se vidljivi aspekti integracije ne ostvaruju brzo. Pored toga, autor ističe da sporiji tempo može ometati inovacije i sprečavati kompanije $u$ ostvarivanju sinergija.

Colombo i ostali (2007) naglašavaju da nije dovoljno preduzeti adekvatne aktivnosti za ostvarenje akvizicionih ciljeva, već je neophodno da se one preduzmu sa maksimalnom urgentnošću.

Istraživanje Homburg-a i Bucerius-a (2005) imalo je za cilj da sagleda uticaj postakvizicione marketing integracije na performanse i efekte brzine integracije. Rezultati su pokazali slab pozitivni direktni efekat između brzine integracije i performansi (baziranih na promeni cena akcija) nakon merdžera ili akvizicije. U novijem radu Homburg i Bucerius (2006) ističu da postoje prednosti, ali i nedostaci brze integracije i da $\mathrm{u}$ određenim situacijama brzina može doneti veliku korist, dok u drugim može negativno da utiče na uspeh akvizicija. Po njima, prednosti i nedostaci zavise od postojanja eksterne (ciljna tržišta i tržišno pozicioniranje) i interne (na primer, menadžment stil) povezanosti preduzeća pre akvizicije. Rezultati istraživanja pokazali su da brzina donosi koristi kada je eksterna povezanost niska, a $\mathrm{u}$ isto vreme interna povezanost visoka.
Pojedini autori smatraju da, pod određenim uslovima, sporiji pristup postakvizicionojintegraciji može biti bolji od bržeg pristupa (Bragado (1992), prema: Homburg \& Bucerius, 2006, 348). Ključni argument koji navodi Bragado jeste da je neophodan period proučavanja i razumevanja između zaposlenih dve kompanije. Ovaj autor ističe da adekvatna brzina integracije zavisi od "usklađenosti" uključenih firmi, posebno od njihove kulturološke usklađenosti.

Određeni broj konsultantskih firmi objavio je rezultate empirijskih studija o performansama merdžera i akvizicija u kojima se razmatra uloga brzine kao potencijalnog faktora uspeha (Harbison et al, 1999; PriceWaterhouseCoopers, 2000; Wyman et al, 2008). Ove studije pružaju izvesne podatke o tome da brzina integracije može pozitivno da utiče na uspeh merdžera i akvizicija. Obično se ističe da je brza implementacija promena korisna zato što minimizira neizvesnost među zaposlenima kombinovanih preduzeća.

Studija Harbison-a i ostalih (1999) pokazala je da, ukoliko su kompanije nejednake po veličini, integracija treba biti brža u odnosu na kompanije koje su sličnih veličina (Slika 3).

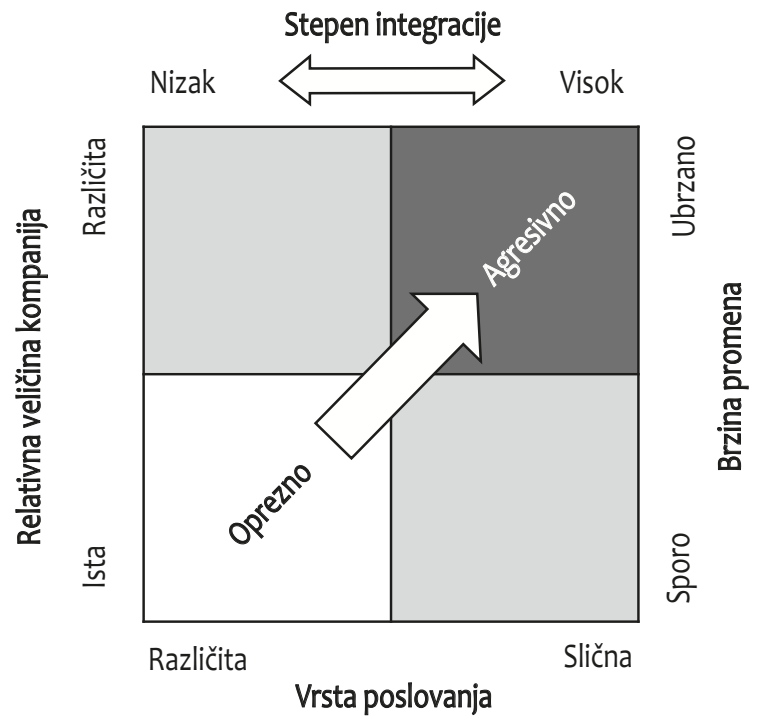

Slika 3 Stepen i brzina integracije

Izvor: Harbison et al, 1999, 12 
Istraživanje Atos Consulting-a (2008) potvrdilo je važnost brzine i jasno pokazalo da veliki broj organizacija preferira brzinu prilikom realizacije ciljeva integracije.

Istraživanje PricewaterhouseCoopers (2000) pokazalo je da, iako se sve kompanije suočavaju sa razlikama u operativnim filozofijama, praksama upravljanja i informacionim sistemima, one koje brže sprovode transakcije imaju znatno manje problema od onih koje su sporije. Sporije transakcije produžavaju integracione probleme dok kompanije koje sprovode proces integracije brže prevazilaze debatu "moja praksa je bolja od vaše prakse" i prateće probleme. Prolongirane transakcije uzrokuju dodatne troškove, sporiji rast, uništavaju profit i smanjuju novčani tok, čime se prolongira plaćanje. Ovo istraživanje je pokazalo da koristi bržih transakcija mogu biti sledeće: brže ostvarivanje prinosa na investiciju, iskorišćavanje mogućnosti u periodu nakon preuzimanja, frustracije konkurenta $\mathrm{u}$ pokušaju da ostvari prednost, smanjivanje organizacione neizvesnosti. Kompanije koje brže sprovode postakvizicionu integraciju imaju veće šanse za ostvarivanje finansijskog i strategijskog uspeha. Među kompanijama koje su brzo sprovele neophodne promene, $75 \%$ smatra da su njihove transakcije bile strategijski uspešne, a $58 \%$ da su finansijski uspešne. Procenti uspeha kod kompanija koje su imale duži tranzitorni period su značajno niži $43 \%$ i $24 \%$ respektivno (Grafikon 1).

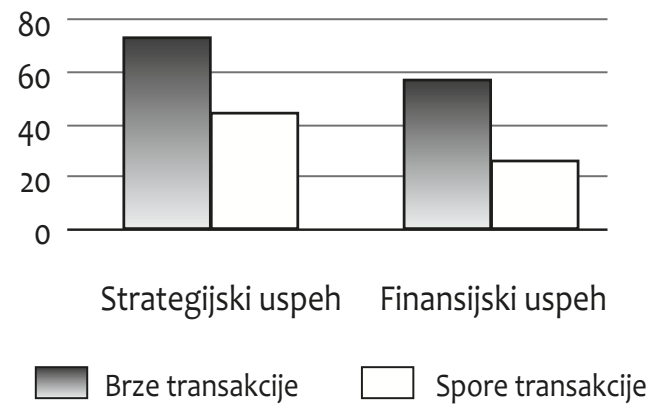

Grafikon 1 Ostvarivanje finansijskog i strategijskog uspeha $u$ zavisnosti od brzine integracije

Izvor: PricewaterhouseCoopers, 2000
Kompanijekojebrže prolaze kroz tranzitorni period brže su u sprovođenju procesa integracije i komuniciranju svojih novih politika i operativnih procedura i ostvaruju više bruto marže i profite (Grafikon 2). Pored toga, brže transakcije imaju povoljniji efekat na novčane tokove i progres u ostvarivanju poslovnih ciljeva. Rano formulisanje integracionih politika i procedura ukazuje na to da menadžment pruža neophodne informacije zaposlenima. Međutim, menadžment mora prvo da bude siguran da nove politike i procedure podržavaju ukupnu poslovnu strategiju i da su dobro shvaćene unutar organizacije.

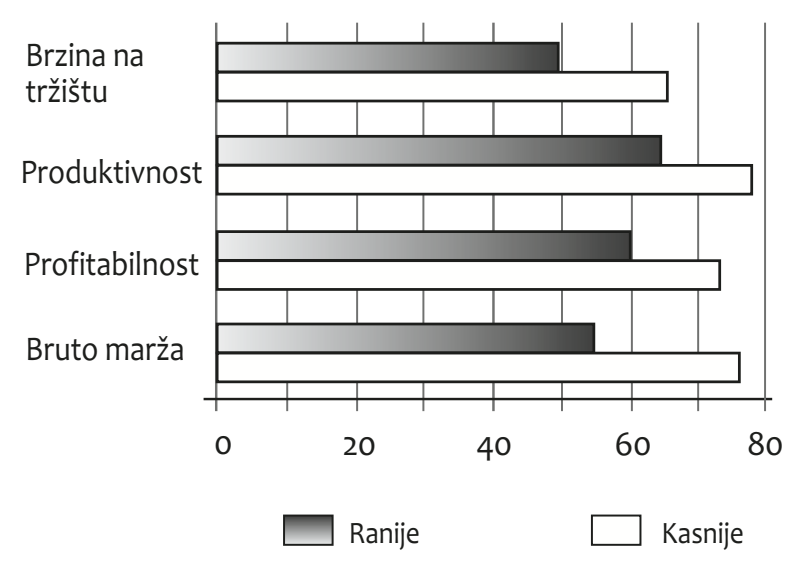

Grafikon 2 Uticaj brzine integracije na poboljšanje performansi

Izvor: PricewaterhouseCoopers, 2000

Wyman i ostali (2008) smatraju da brzina integracije zavisi od tipa preuzimanja i da kod neprijateljskih preuzimanja treba sprovoditi bržu integraciju dok kod prijateljskog preuzimanja sporiji tempo može povećati šanse za uspeh.

Iako svi autori nemaju jedinstven stav o uticaju brzine na uspeh postakvizicione integracije, ipak preovlađuju mišljenja o pozitivnom efektu brzine. Najčešći pozitivni efekti brzine integracije koji su navođeni odnose se na ublažavanje neizvesnosti, bržu realizaciju prinosa, kraće vreme koje se posvećuje koordinaciji, brže ostvarivanje poslovnih ciljeva, povećanje verovatnoće ostvarivanja finansijskog i strategijskog uspeha. 


\section{ZAKLJUČAK}

Transakcije preuzimanja preduzeća uključuju visok rizik i zahtevaju izuzetnu pažnju u procesu planiranja i implementacije, kako bi se ostvarili željeni ciljevi i omogućilo kreiranje vrednosti. Kako je očigledno da do kreiranja vrednosti dolazi nakon preuzimanja, $\mathrm{u}$ novije vreme postakviziciona integracija privlači sve veću pažnju istraživača. Kao jedan od glavnih uzroka neuspeha merdžera i akvizicija navodi se loše sproveden proces postakvizicione integracije. Otuda se, kao nužni uslov, nameće neophodnost detaljnog sagledavanja mehanizama integrisanja, identifikovanja izvora vrednosti i mogućih problema i izazova $u$ okviru faze integracije. Osnovni izvori vrednosti su raspodela resursa, transfer znanja i transfer upravljačkih veština dok se ključni problemi koji uzrokuju destrukciju vrednosti odnose na postojanje rezistentnosti zaposlenih i nekompatibilnost kultura. Prevazilaženje integracionih problema, koji mogu biti prepreka uspehu merdžera i akvizicija, moguće je postići adekvatnim upravljanjem postakvizicionim aktivnostima.

U postupku identifikovanja faktora koji imaju ključni značaj za uspeh postakvizicione integracije, a samim tim i za uspeh merdžera i akvizicija, iskristalisali su se različiti faktori, a posebna važnost se pridaje brzini integracije. Ne postoji potpuna usaglašenost stavova autora o efektima brzine, ali preovlađujuće mišljenje da brzina ima ključni značaj za ostvarenje strategijskih ciljeva, promovisanje stabilnosti i smanjenje neizvesnosti u organizaciji. Da bi preduzeće uspešno sprovelo proces postakvizicione integracije, neophodno je da kreira novu viziju za nov entitet, izvrši detaljno planiranje, shvatajući značaj strategijskog liderstva koje pomaže u sprovođenju neizbežnih promena i brzo pokreće sposobnosti novog preduzeća ka ostvarivanju maksimalnog profita. Sposobnost da se brzo izvrši integracija, redukuju operativni troškovi i generiše dodatni prinos postaje glavni faktor ostvarivanja dobrih performansi.

Imajući u vidu činjenicu da procesi merdžera i akvizicija u Srbiji postaju aktuelni tek u novije vreme, navedena problematika nije dovoljno istražena. Otuda postoji potreba za empirijskim istraživanjem kojim bi se na metodološki validan način ispitao proces postakvizicione integracije $\mathrm{u}$ cilju boljeg razumevanja faktora koji determinišu uspeh datog procesa i ukupni uspeh merdžera i akvizicija. Sveobuhvatna teorijska i empirijska analiza navedenog problema omogućila bi komparaciju dobijenih rezultata sa rezultatima istraživanja u razvijenim tržišnim privredama.

\section{ZAHVALNICA}

Ovaj rad je deo interdisiplinarnog istraživačkog Projekta (br. 41010), koji finansira Ministarstvo nauke Republike Srbije.

\section{REFERENCE}

Adolph, G., Buchanan, I., Hornery, J., Jackson, B., Jones, J., Kihlstedt, T., Neilson, G., \& Quarls, H. (2001). Merger Integration: Delivering on the Promise. Booz Allen \& Hamilton. Retrieved April 10, 2010, from http://www.boozallen.com/ media/file/76776.pdf.

Agrawal, S., Dasgupta, A., \& Bansal S. (2011). Putting the pieces together - Post merger integration survey 2010, PwC India. Retrieved March 08, 2011, from http://www.pwc.com/in/en/ publications/publications-2011/putting-the-pieces-together. jhtml.

Atos Consulting. (2008). Post-merger Integration of It, White Paper - Challenging the CIO Before and After the Deal. Atos Origin., 1-16. Retrieved March 08, 2011, from http://www. be.atosconsulting.com/NR/rdonlyres/C8A81F41-6DE64DDD-9A63-930343774B91/0/AtosConsulting_Whitepaper_ PostMerger_Integration_of_IT_uk.pdf.

Babic, V., \& Savovic, S. (2009). Značaj liderstva za uspeh procesa preuzimanja preduzeća. Ekonomske teme, 1, 74-61.

Birkinshaw, J., Bresman, H., \& Hakanson, L. (2000). Managing the Post-Acquisition Integration Process: How the Human Integration and Task Integration Processes Interact to Foster Value Creation. Journal of Management Studies, 37(3), 395-421.

Chakrabarti, A., \& Mitchell, W. (2004). A Corporate Level Perspective on Acquisitions and Integration. Retrieved February, 15, 2011, from http://faculty.fuqua.duke.edu/ willm/bio/cv/ papers/AIMA2004_integration.pdf.

Colombo, G., Conca, V., Buongiorno, M., \& Gnan, L. (2007). Integrating Cross-Border Acquisitions: A Process-oriented Approach. Long Range Planning, 40, 202-222. 
De Noble, A., Gustafson, L., \& Hergert, M. (1997). Planning for Post-merger Integration - Eight Lessons for Merger Success. In B. Lloyd (Ed.), Creating Value through Acquisitions, Demergers, Buyouts and Alliances (pp 51-59).

Datta, K. D. (1991). Organizational Fit and Acquisition Performance-Effects of Post-acquisition Integration. Strategic Management Journal. In Risberg, A., (2006). Mergers and Acquisitions - A Critical Reader. Routledge Taylor \& Francis Group.

Elsass, M. P., \& Veiga, F. J. (1994). Acculturation in Acquired Organizations: A Force-field Perspective. Human Relations. In Risberg, A. (2006). Mergers and Acquisitions A Critical Reader. Routledge Taylor \& Francis Group.

Epstein, M. (2004). The Drivers of Success in Post-Merger Integration, Organizational Dynamics, 33(2), 174-189.

Fanlkner, D., \& Cambell, A. (2003). The Oxford Handbook of Strategy. Vol II: Corporate Strategy. Oxford: Oxford University Press.

Gates, S., \& Very, P. (2003). Measuring Performance during M\&A Integration. Long Range Planning, 36, 167-185.

Habeck, M., Kröger, F., \& Träm, M. (2000). After the Merger Seven Rules for Successful Post-Merger Integration. Pearson Education Limited.

Haspeslagh, \& Jemison. (1991). In Fanlkner D., \& Cambell A. (2003). The Oxford Handbook of Strategy. Vol II: Corporate Strategy. Oxford: Oxford University Press.

Harbison, R. J., Viscio, J. A., \& Asin, T.A. (1999). Making Acquisitions Work: Capturing Value after the Deal. Fourth in a Series of Viewpoints on Alliances, Booz Allen \& Hamilton Inc., 1-20. Retrieved April, 242009 from http://www. boozallen.com/media/file/33886.pdf.

Homburg, C., \& Bucerius, M. (2005). A Marketing Perspective on Mergers and Acquisitions: How Marketing Integration affects Postmerger Performance. The Journal of Marketing, 69(1), 95-113.

Homburg, C., \& Bucerius, M. (2006). Is speed of integration really a success factor of mergers and acquisitions? An analysis of role of internal and external relatedness. Strategic Management Journal, 27(4), 347-367.

Kelly, J., Cook, C., \& Spitzer, D. (1999). Mergers \& Acquisitions: Global Research Report. KPMG, 1-21. Retrieved March 12, 2009 from http://people.stern.nyu.edu/adamodar/pdfiles/eqnotes/ KPMGM\&A.pdf.

Kimberly, E., \& Lamont, B. (2004). “Ideal"acquisition integration approaches in related acquisitions of equals: a test of longheld beliefs. Advances in Mergers and Acquisitions, 3, 81-102.
Larsson, R., \& Finkelstein, S. (1999). Integrating Strategic, Organizational, and Human Resource Perspectives on Mergers and Acquisitions: A Case Survey of Synergy Realization. Organization Science, 10(1), 1-26.

Marks, M. L., \& Mirvis, P. H. (1986). The Merger Syndrome, Psychology Today. In A. Risberg, (2006). Mergers and acquisition A Critical Reader. Routledge Taylor \& Francis Group.

Marks, M. L., \& Mirvis, P. H. (2001). Making mergers and acquisitions work: Strategic and psychological preparation. The Academy of Management Executive, 15(2), 80- 92.

Nahavandi, A., \& Malekzadeh, A. (1988). Acculturation in Mergers and Acquisitions. The Academy of Management Review, 13(1), 79-90.

Nemanich, L., \& Vera, D. (2009). Transformational leadership and ambidexterity in the context of an acquisition. The Leadership Quarterly, 20, 19-33.

Pablo, A. (1994). Determinants of acquisition integration level: a decision-making perspective. Academy of Management Journal, 37(4), 803-836.

Pitkethly, R., Faulkner, D., \& Child, J. (2003). Integrating Acquisitions. Advances in Mergers and Acquisitions, 2, 27-57.

PricewaterhouseCoopers. (2000). Speed Makes the Difference - A Survey of Mergers and Acquisitions. PricewaterhouseCoopers LLP. Retrieved March 10, 2011, from http://www.sysedv.tuberlin.de/intranet/kc-kb.nsf/bc64cc33c3daf5fec1256979005 bc026/29CC7F0767AECFD9C1256CDA00354346/\$File/PWCM\&A2.pdf?OpenElement.

Schweiger, D. M., \& DeNisi A. S. (1991). Communication with Employees Following a Merger: A Longitudinal Field Experiment. In Risberg, A. (2006). Mergers and Acquisitions - A Critical Reader, Routledge Taylor \& Francis Group.

Schweizer, L., \& Patzelt, H. (2012). Employee commitment in the post-acquisition integration process: The effect of integration speed and leadership. Scandinavian Journal of Management, 28(4), 298-310.

Shrivastava, P. (1986). Post-merger integration. Journal of Business Strategy, 7(1), 65-76.

Teerikangas, S. (2006). Silent Forces in Cross-Border Acquisitions - An Integrative Perspective on Post-Acquisition Integration. Unpublished doctoral dissertation, Helsinki University of Technology Institute of Strategy and International Business. Retrieved October 10, 2010 from https://aaltodoc. aalto.fi/bitstream/handle/123456789/2691/isbn9512280930. pdf?sequence $=1$. 
Wyman, O., Kautzsch, T., Thormählen, H., \& Vratimos, E. (2008). Post-merger integration - A tailored approach to sustainable transaction success. 1-16. Retrieved March 5, 2011, from www.oliverwyman.com/ow/pdf.../Post_Merger_ Integration_en.pdf.

Primljeno 04. jula 2012, nakon revizije, prihvaćeno za publikovanje 12. decembra 2012.

Slađana Savović je asistent na nastavnom predmetu Ekonomika preduzeća, na Ekonomskom fakultetu Univerziteta u Kragujevcu, gde je magistrirala u oblasti poslovne ekonomije. Osnovna područja istraživačkog rada su tržište korporativne kontrole i procesi preuzimanja preduzeća.

\title{
THE IMPORTANCE OF POST-ACQUISITION INTEGRATION FOR VALUE CREATION AND SUCCESS OF MERGERS AND ACQUISITIONS
}

\author{
Sladjana Savovic \\ Faculty of Economics, University of Kragujevac, Kragujevac, Serbia
}

Companies often resort to mergers and acquisitions in order to gain access to new markets, introduce new products, expand their knowledge-base or improve the competitive advantage. Achieving success in mergers and acquisitions represents complex managerial challenges, as a great number of these transactions fail in creating value for shareholders. Post-acquisition integration is the most challenging phase during which value creation should be involved, but which may also involve numerous integration problems. This study puts an emphasis on the success factors of the post-acquisition integration of companies, such as an integration strategy, the composition of the integration team, communications, the speed of the integration process and the uniformity of measurements. A special emphasis is put on the importance of the speed of integration as a success factor of the post-acquisition integration of companies.

Keywords: post-acquisition integration, key success factors, integration speed, success of mergers and acquisitions 